\title{
Occurrence, Distribution, and Ecological Risk Assessment of Emerging and Legacy Contaminants in the Kadicha River in Lebanon
}

Fatme Merhabi ( $\square$ merhabi10@gmail.com )

Lebanese University: Universite Libanaise https://orcid.org/0000-0002-9814-6483

\section{Elena Gomez}

University of Montpellier: Universite de Montpellier

Helmieh Amine

Lebanese University: Universite Libanaise

\section{David Rosain}

University of Montpellier: Universite de Montpellier

Jalal Halwani

Lebanese University: Universite Libanaise

Hélène Fenet

Montpellier University: Universite de Montpellier

\section{Research Article}

Keywords: Mediterranean river , Kadicha river , Emerging contaminants , legacy contaminants , Sediments , Urbanization , Environmental risk assessment

Posted Date: April 13th, 2021

DOI: https://doi.org/10.21203/rs.3.rs-341586/v1

License: @ (i) This work is licensed under a Creative Commons Attribution 4.0 International License. Read Full License

Version of Record: A version of this preprint was published at Environmental Science and Pollution Research on July 1st, 2021. See the published version at https://doi.org/10.1007/s11356-021-15049-0. 


\section{Abstract}

The Kadicha river basin in Northern Lebanon is an illustrative example of multiple pressures encountered in the Mediterranean region: it is a small coastal river affected by rapid urbanization, population growth (drastically impacted by the influx of Syrian refugees), and a chronic default of wastewater treatment. In this context, multiple classes of contaminants may attain the river accumulating in sediment. However, very little information is available in the literature on the contamination status in such stressed Mediterranean contexts. This study proposed a first contamination evaluation of a small Mediterranean river submitted to multiple pressures. Two sediment sampling campaigns along sites impacted by increasing urban gradient within the Kadicha river basin were performed to determine the occurrence and the environmental risks of both emerging and legacy contaminants. The results revealed the detection of the 41 studied compounds. The highest concentrations were attained by PAHs and polycyclic musks (up to $311.79,94.22$, and $81.13 \mathrm{ng} / \mathrm{g}$ of dry weight for PAH, cashmeran, and galaxolide, respectively). The discontinuous urbanized upstream area and the estuary were the most contaminated areas of the river. An environmental risk assessment showed a hazard quotient (HQ) higher than 1 for both legacy and emerging compounds (EHMC and 4-MBC), indicating a potential risk to benthic species. Monitoring campaigns and implementation of wastewater treatment plants should be encouraged as the anthropogenic pressure on small Mediterranean rivers will increase over the years.

\section{Highlights}

- First comparative study between legacy and emerging contaminants in terms of occurrence and potential risks in a Lebanese watershed.

- Polycyclic aromatic hydrocarbons and polycyclic musks (cashmeran and galaxolide) were detected at the highest concentrations in sediments.

- Anthropogenic activities were the major sources of inputs of legacy and emerging contaminants (e.g., discharge of wastewaters and leachates, vehicle transport).

- The risk assessment indicates that both legacy and emerging contaminants pose potential risks for benthic species.

\section{Introduction}

The Mediterranean basin region has been affected for millennia by human activities. Today, the Mediterranean basin suffers from disturbances derived from agriculture, livestock, industrial practices, and human population growth. Anthropogenic activities within the Mediterranean rivers' watersheds have resulted in changes in fluvial geomorphology, organic matter dynamics, and increases in pollution and salinity (Cooper et al., 2013). The large rivers constitute the major contributors to pollution input into the sea (Ludwig and Probst, 1998; Roy et al., 1999; Abril et al., 2002). However, small Mediterranean rivers contribute to the pollution, especially where population density is high, causing environmental and health risks in river watersheds and bringing to the sea the contamination occurring in the coastal area (Kolpin et al., 2004; Nicolau et al., 2012). All these anthropogenic activities within small Mediterranean watersheds were associated with the releasing of different pollutants, known as persistent organic pollutants (POPs) and emerging pollutants. Historically, POPs (e.g. polycyclic aromatic hydrocarbons (PAHs) and polychlorinated biphenyls (PCBs)) have been monitored and regulated in most parts of the world for the last decades, that's why they are referred to as "legacy contaminants" (Jones and 
De Voogt, 1999; Lohmann et al., 2007). Other contaminants are still little or not regulated and not included in routine monitoring programs (Pintado-Herrera et al., 2016). These contaminants referred to as "emerging contaminants" include personal care products (PCP) (e.g. ultraviolet filters and stabilizers and fragrances), insecticides (pyrethroids), biocides, and surfactants (alkylphenols (APs)). However, some emerging contaminants are regulated for future prioritization exercises: the watch list of the European Union Decision 2015/495/ EU identifies an organic ultraviolet filter (2-ethyl-hexyl-4-trimethoxycinnamate, (EHMC)) among priority substances; the Directive 2013/39 / EU includes a pyrethroid (cypermethrin) as a priority substance; and the water framework directive of the European Parliament 2008/105 / EC, establishing environmental quality standards in the field of water policy, identifies APs (nonylphenols and octylphenols) as hazardous substances considered as priority substances.

The cited legacy and emerging substances are released in small Mediterranean rivers: PAHs and PCBs enter the aquatic environment through industrial wastewater discharge, urban runoff, and atmospheric deposition (Maher and Aislabie, 1992; Totten et al., 2006; Barbosa et al., 2012; Liu et al., 2015). Emerging substances such as ultraviolet filters and stabilizers (UVFs and UVSs), fragrances such as polycyclic musks (PCMs), antimicrobials, and alkylphenols enter surface waters through domestic wastewater effluents and landfill leachates (Ying et al., 2002; Giokas et al., 2007; Wang and Kelly, 2017). Moreover, PCMs are semi-volatile compounds that can enter surface waters after long-term atmospheric transport (Peck and Hornbuckle, 2004; Peck et al., 2006). Pyrethroids in insecticides used for agricultural and residential pest control enter the aquatic environment through dry and wet deposition processes, and residential and agricultural runoff (Majewski et al., 1998; Chalányová et al., 2006; Weston et al., 2009).

Once released into the river environment, the aforementioned legacy and emerging contaminants accumulate into the sediment considered as a sink for these pollutants due to their low solubility and high octanol-water partition coefficient (log Kow) (Zhao et al., 2010; Li et al., 2014; Goswami et al., 2016). Accumulation of legacy and emerging contaminants in sediment may pose risks for wildlife especially for benthic species because these chemicals can be bio-accumulative in organisms and even be bio- transferable in food chains (Jones and De Voogt, 1999; Peng et al., 2017). Also, PAHs and PCBs present a risk to human health and the ecosystems due to their carcinogenic potential (Sindermann, 2005). Some emerging contaminants (UVFs EHMC and 4-MBC) are endocrine disruptors with antiandrogenic and antiestrogenic effects (Balázs et al., 2016). Despite these different potential risks associated with legacy and emerging contaminants, few studies have focused on the assessment of small Mediterranean rivers situation, especially in the eastern Mediterranean. Few studies have been conducted on the occurrence of POPs and emerging contaminants in Lebanese riverine sediments (Thomas et al., 2005; Amine et al., 2012; Amine et al., 2018a; Amine et al., 2018b). Comparatives studies between the occurrence of PAHs, UVFs, and APs within transition zones of small Mediterranean rivers in Northern Lebanon, El Kebir, El Bared, and Kadicha rivers, pointed out that the highest levels of the studied contaminants were within the Kadicha river (Amine et al., 2012; Amine et al., 2018a; Amine et al., 2018b). The presence of such contamination shows that the Kadicha river presents the most significant anthropogenic pressure compared to the other two rivers.

While some legacy contaminants have been banned from production, the usage of emerging contaminants has increased significantly in recent years. This has led to an emerging scientific problem on how emerging contaminants contribute to the pollution of aquatic environments and the evolution of toxicity for living organisms compared to legacy contaminants. This question deserved to be addressed in small Mediterranean 
rivers. Moreover, to the best of our knowledge, there is not any comparative study between legacy and emerging contaminants in terms of occurrence and potential risks in Lebanon. Furthermore, emerging contaminants are not part of monitoring programs and surveys in Lebanon. Thus, occurrence data for these contaminants in this country are lacking. In this context, the objectives of the present study were: i) to determine the distribution, composition, sources, and pollution levels of selected emerging and legacy contaminants in the Kadicha river basin, and ii) to discuss their potential toxicological impacts on the local environment.

\section{Materials And Methods}

\section{Reagents and standards}

The compounds selected for the study were 41 organic pollutants belonging to eight different classes: Pyrethroids, UVFs, UVSs, PCMs, biocides, APs, PAHs, and PCBs. The pyrethroids were: bifenthrine (BIF), cypermethrin (CYP), deltamethrin (DELT), and permethrin (PER) (purchased from Sigma-Aldrich (USA)). The 5 UVFs were: EHMC, octocrylene (OC), octyldimethyl p-amino benzoic acid (ODPABA), 4-methylbenzylidene camphor (4-MBC) (purchased from Sigma-Aldrich Merck Fluka), and 2-ethylhexylsalicylate (EHS) (purchased from ChemCruz). The UVSs were: 2-tert-butyl-6-(5-chloro-2H-benzotriazol-2-yl)-4-methylphenol (UV-326) and 2-(2hydroxy-5-methylphenyl)benzotriazole (UV-P) (purchased from Sigma-Adrich, Merck, Fluka). The PCMs were: galaxolide (HHCB), celestolide (ADBI), cashmeran (DPMI), tonalide (AHTN) (purchased from Sigma-Adrich, Merck, Fluka), and tetramethyl acetyloctahydronaphthalene (OTNE) (obtained from Santa Cruz (USA)). The APs were: 4n-nonylphenol (4n-NP) (purchased from Sigma-Aldrich (St Quentin Fallavier, France)) and 4-tertoctylphenol (4-t-OP) (purchased from Cluzeau (Courbevoie, France)). The 2 biocides, irgarol (purchased from chemCruz) and methyl triclosan (MTCS) (purchased from Sigma-Aldrich). The 16 PAHs set as priority pollutants by the United States Environmental Protection Agency (United States Environmental Protection Agency (EPA), 2001) were: naphthalene (Naph), acenaphthylene (Acy), acenaphthene (Ace), fluorene (Flu), phenanthrene (Phe), anthracene (Ant), fluoranthene (Flt), pyrene (Pyr), benzo[a]anthracene (BaA), chrysene (Chr), benzo[b]fluoranthene $(\mathrm{BbF})$, benzo[k]fluoranthene $(\mathrm{BkF})$, benzo[a]pyrene $(\mathrm{BaP})$, indeno[1,2,3-cd]pyrene (Ind), dibenz[a,h]anthracene (DahA), and benzo[g,h,i]perylene (BghiP). PAHs were obtained as a set of a mixed standard solution in cyclohexane at $10 \mathrm{ng} / \mu \mathrm{L}$ from Dr. Ehrenstorfer, $\mathrm{GmbH}$. The PCBs were: PCB 52, PCB 101, PCB 153, PCB 138 and PCB 180. They were obtained as a set of a mixed solution in isooctane at $10 \mathrm{ng} / \mu \mathrm{L}$ from Sigma-Aldrich (St Quentin Fallavier, France). In addition, the following substances were used as surrogate standards: Acenaphthene-d10, Phenanthrene-d10, Chrysene-d12 (purchased from Supelco), 4-MBC-d4, and 4-nNP-2,3,5,6-D4-OD (purchased from Cluzeau, Courbevoie, France). PCB 30, purchased from Dr. Ehrenstorfer, $\mathrm{GmbH}$, was used as an internal standard. All the molecules were purchased at the analytical level (purity $>90 \%$ ). Analytical grade heptane, ethanol, and methanol were supplied by Carlo Erba (Val de Reuil, France).

Standard solutions of individual compounds were prepared at a concentration of $1 \mathrm{mg} / \mathrm{mL}$. All standard solutions were stocked at $-20^{\circ} \mathrm{C}$. Working solutions were prepared by appropriate dilution of the stock solution in heptane.

Diatomaceous earth used as a dispersing agent and neutral alumina and copper used as sorbents for sample clean-up were all purchased from Sigma-Aldrich (St Louis, USA). Gloves were worn during all the sampling preparation to avoid contamination at low levels. 


\section{Study area and sampling}

The Kadicha river in north Lebanon also known as "Abou Ali" is a small Mediterranean river affected by rapid urbanization and population growth. The river land use watershed is representative of modern anthropization in most of the Mediterranean rivers: mixing urban, discontinuous urban, and rural areas with agricultural, recreational activities and small industrial facilities. The residential wastewaters are discharged directly to the flood channel without prior treatment (Naja and Volesky, 2013). Besides, an open area dumpsite at the estuary of the river receiving urban solid waste releases approximately 24000 metric tons of leachate per year in the estuary (or the lower part) of the river (Naja and Volesky, 2013). Recently, the downstream of this watershed have shown a population growth after the arrival of Syrian refugees (AEMS, 2017) which may lead to an increase in anthropogenic pressure.

The Kadicha river is characterized by a Mediterranean climate with a moderately warm and dry summer and autumn, and moderately cold, windy, and wet winters with almost $80-90 \%$ of total precipitation occurring between November and March (Massoud et al., 2006). The Kadicha river flows into the Mediterranean Sea, with a basin draining a total of $484 \mathrm{~km}^{2}$ (SOER, 2001). The river basin has a length of $44.5 \mathrm{~km}$ and an average annual discharge of 262 million $\mathrm{m}^{3}$ (SOER, 2001). The sampling sites are presented in Figure 1. The land use of the river basin mapped out using the QGIS software showed that the upstream of the river is dominated by agricultural surfaces with some discontinuous urban tissues while the downstream is mainly urbanized. The river's waters are mainly used for domestic supply, hydroelectric production, irrigation, and recreational activities. Groundwater is the main source of drinking water for residents within the basin.

Twelve sampling sites were selected to realize the possible compromise between representativeness of potentially polluted sites and operational feasibility. The selected sites are described in Table 1 in terms of geographic location and anthropogenic pressures. Three sites (Koussba (Ks), Bshennine (Bs), and Bkeftine (Bk)) were in the rural upstream area designated RU. Four sites (Meryata (Myt), Ardeh (Ar), Al Merdechyeh (Mr), and Zgharta (Zgh)) were in the discontinuous urbanized upstream area designated DUU. These 2 areas are influenced by agricultural activities with DUU area gathering a higher density of population than RU area (Table 1). Five sites were in the coastal plain occupied by the city of Tripoli: 3 sites (Abou Samra (T-Ab1 and T-Ab2) and Al Marjeh (T-Mj)) in the urbanized downstream area designated UD and 2 sites (EAA-1 and EAA-2) in the estuary designated EST. Tripoli is highly urbanized with a population estimated to 500000 inhabitants (UNEP, 2009). This population has increased after the Syrian crisis. According to UNHCR, the number of Syrian refugees in Tripoli registered as of 30 June 2016, including 7 percent of non-registered displaced Syrians living in informal settlements, reached 52350 (or 13644 families) (AEMS, 2017). The sewage of Tripoli city is discharged into surface water streams or directly through short sea outfalls without prior treatment (Naja and Volesky, 2013). The population density at each sampling site was estimated according to the site Population Data.net (https://www.populationdata.net/cartes/liban-densite-2004/).

Table 1

Characteristics and land use context of the 12 sampling sites RU Rural Upstream, DUU Discontinuous Urbanized Upstream, UD Urbanized Downstream, and EST Estuary. 


\begin{tabular}{|c|c|c|c|c|}
\hline Site & Code & $\begin{array}{l}\text { Zone } \\
\text { GPS } \\
\text { coordinates }\end{array}$ & Anthropogenic activities & $\begin{array}{l}\begin{array}{l}\text { Population } \\
\text { density } \\
\text { (inhabitants } / \mathrm{Km}^{2} \text { ) }\end{array} \\
\text { Urban pressure }\end{array}$ \\
\hline Koussba & Ks & $\begin{array}{l}\mathrm{RU} \\
34^{\circ} 18^{\prime} 22.72^{\prime \prime} \mathrm{N} \\
35^{\circ} 51^{\prime} 50.09^{\prime \prime} \mathrm{E}\end{array}$ & $\begin{array}{l}\text { agricultural and recreational activities - no } \\
\text { direct discharge }\end{array}$ & $\begin{array}{l}100-250 \\
\text { No pressure }\end{array}$ \\
\hline Bshennine & Bs & $\begin{array}{l}\text { RU } \\
34^{\circ} 20^{\prime} 25,69^{\prime \prime} \mathrm{N} \\
35^{\circ} 51^{\prime} 18,24^{\prime \prime} \mathrm{E}\end{array}$ & $\begin{array}{l}\text { agricultural and farm activities - direct } \\
\text { discharge of waste of a pig farm }\end{array}$ & $\begin{array}{l}100-250 \\
\text { No pressure }\end{array}$ \\
\hline Bkeftine & Bk & $\begin{array}{l}\mathrm{RU} \\
34^{\circ} 23^{\prime} 58.03^{\prime \prime} \mathrm{N} \\
35^{\circ} 52^{\prime} 20.57^{\prime \prime} \mathrm{E}\end{array}$ & agricultural activities - open area dumpsite & $\begin{array}{l}250-500 \\
\text { No pressure }\end{array}$ \\
\hline Meryata & Myt & $\begin{array}{l}\text { DUU } \\
34^{\circ} 24^{\prime} 43.33^{\prime \prime} \mathrm{N} \\
35^{\circ} 55^{\prime} 46.31^{\prime \prime} \mathrm{E}\end{array}$ & $\begin{array}{l}\text { agricultural activities - direct discharge of } \\
\text { collected olive mill effluent and sewers }\end{array}$ & $\begin{array}{l}500-1000 \\
\text { Low }\end{array}$ \\
\hline Ardeh & $\operatorname{Ar}$ & $\begin{array}{l}\text { DUU } \\
34^{\circ} 24^{\prime} 10.21^{\prime \prime} \mathrm{N} \\
35^{\circ} 54^{\prime} 32.56^{\prime \prime} \mathrm{E}\end{array}$ & $\begin{array}{l}\text { direct discharge of collected sewers from } \\
\text { villages upstream: Ardeh, HarfArdeh, } \\
\text { Hewarah, and Echech }\end{array}$ & $\begin{array}{l}500-1000 \\
\text { Low }\end{array}$ \\
\hline $\begin{array}{l}\text { Al } \\
\text { Merdechyeh }\end{array}$ & $\mathrm{Mr}$ & $\begin{array}{l}\text { DUU } \\
34^{\circ} 24^{\prime} 2.8^{\prime \prime} \mathrm{N} \\
35^{\circ} 54^{\prime} 3.28^{\prime \prime} \mathrm{E}\end{array}$ & $\begin{array}{l}\text { recreational activities - direct discharge } \\
\text { from restaurants }\end{array}$ & $\begin{array}{l}500-1000 \\
\text { Low }\end{array}$ \\
\hline Zgharta & Zgh & $\begin{array}{l}\text { DUU } \\
34^{\circ} 24^{\prime} 14.21^{\prime \prime} \mathrm{N} \\
35^{\circ} 53^{\prime} 14.23^{\prime \prime} \mathrm{E}\end{array}$ & $\begin{array}{l}\text { agricultural activities - direct discharge of } \\
\text { residential wastewater }\end{array}$ & $\begin{array}{l}1000-2500 \\
\text { High }\end{array}$ \\
\hline $\begin{array}{l}\text { Tripoli Abou } \\
\text { Samra }\end{array}$ & $\begin{array}{l}\text { T- } \\
\text { Ab2 }\end{array}$ & $\begin{array}{l}\text { UD } \\
34^{\circ} 25^{\prime} 9.81^{\prime \prime} \mathrm{N} \\
35^{\circ} 51^{\prime} 21.25^{\prime \prime} \mathrm{E}\end{array}$ & $\begin{array}{l}\text { direct discharge of wastewater of the } \\
\text { residents }\end{array}$ & $\begin{array}{l}1000-2500 * \\
\text { High }\end{array}$ \\
\hline $\begin{array}{l}\text { Tripoli Al } \\
\text { Marjeh }\end{array}$ & T-Mj & $\begin{array}{l}\text { UD } \\
34^{\circ} 25^{\prime} 46^{\prime \prime} \mathrm{N} \\
35^{\circ} 50^{\prime} 55.17^{\prime \prime} \mathrm{E}\end{array}$ & $\begin{array}{l}\text { direct discharge of wastewater of the } \\
\text { residents }\end{array}$ & $\begin{array}{l}1000-2500 * \\
\text { High }\end{array}$ \\
\hline Estuary & $\begin{array}{l}\text { EAA- } \\
1\end{array}$ & $\begin{array}{l}\text { EST } \\
34^{\circ} 27^{\prime} 21.26^{\prime \prime} \mathrm{N} \\
35^{\circ} 50^{\prime} 29.6^{\prime \prime} \mathrm{E}\end{array}$ & $\begin{array}{l}\text { direct discharge of leachate generated by } \\
\text { the open dump area }\end{array}$ & $\begin{array}{l}2500-5000 \\
\text { Very high }\end{array}$ \\
\hline Estuary & $\begin{array}{l}\text { EAA- } \\
2\end{array}$ & $\begin{array}{l}\text { EST } \\
34^{\circ} 27^{\prime} 28^{\prime} .67^{\prime \prime} \mathrm{N} \\
35^{\circ} 50^{\prime} 28.29^{\prime \prime} \mathrm{E}\end{array}$ & $\begin{array}{l}\text { direct discharge of leachate generated by } \\
\text { the open dump area }\end{array}$ & $\begin{array}{l}2500-5000 \\
\text { Very high }\end{array}$ \\
\hline
\end{tabular}


Surface sediments $(0-20 \mathrm{~cm})$ were collected for 3 days in February 2017 (the mid of the wet season) and September 2017 (the end of the dry season) following the Aquaref methods (AQUAREF, 2016). Stainless steel cylindrical shovel, previously rinsed with dichloromethane and acetone was used to collect sediments placed in aluminum containers. Sediments were homogenized, air-dried, and sieved to collect the fraction below $2 \mathrm{~mm}$. Then sediments $(<2 \mathrm{~mm})$ were lyophilized and stored in a dark environment until analysis. Particle size distribution analysis was performed by a LA950V2 with 2 minutes of ultrasound to ensure complete separation of all particles. All data is provided by the LA950 software. Total Organic Carbon (TOC) was analyzed in sediments with a HighTOC II analyzer.

\section{Sediment extraction}

Extraction of analytes from sediment samples was achieved by pressurized liquid extraction (PLE) using an accelerated solvent extractor ASE 350 unit from Dionex equipped with $22 \mathrm{~mL}$ stainless-steel cells. A mass of $2 \mathrm{~g}$ of sediments previously homogenized with $1.5 \mathrm{~g}$ of diatomaceous earth was extracted. Purification of the extracts was performed simultaneously to the extraction (in-cell clean-up) by placing sorbents inside the cell (activated alumina and copper) according to the procedures reported by Pintado-Herrera et al., (2016).

Surrogates acenaphthene $\mathrm{d} 10$, phenanthrene $\mathrm{d} 10$, chrysene $\mathrm{d} 12,4-\mathrm{MBC} \mathrm{d} 4$, and 4n-NP-2,3,5,6-d4,OD were spiked at $50 \mathrm{ng} / \mathrm{g}$ to sediment samples $24 \mathrm{~h}$ before extraction to account for losses during the extraction procedure. A mixture of 1:1 acetone and heptane was selected as the extraction solvent, using four static extraction cycles of 6 minutes each (purge time $=300 \mathrm{~s}$, flush volume $=60 \%$ ), $125^{\circ} \mathrm{C}$, and $1500 \mathrm{psi}$. These parameters are reported by US EPA (US EPA, 2007). PLE extracts $(80 \mathrm{~mL}$ ) were evaporated to dryness using a Multivap (Büchi, Switzerland) and redissolved in $1 \mathrm{~mL}$ of heptane which was filtered through PTFE centrifuge filters $(0.22 \mu \mathrm{m}$ pore size). The internal standard PCB 30 was added at $50 \mathrm{ng} / \mathrm{mL}$ to correct possible fluctuations during GCMS/MS analysis.

\section{GC-MS/MS analysis}

The separation, identification, and quantification of the 41 molecules were performed using gas chromatography coupled to triple quadrupole mass spectrometry. Capillary gas chromatography analysis was carried out on a Macherey-Nagel column ( $30 \mathrm{~m} \times 0.25 \mathrm{~mm}$ i.d. $\times 0.25 \mathrm{~m}$ film thickness), keeping the carrier gas flow (helium) at $1.7 \mathrm{~mL} \cdot \mathrm{min}^{-1}$, and the transfer line and the temperature of the source at 300 and $250{ }^{\circ} \mathrm{C}$ respectively. The column temperature ramp was as follows: $78^{\circ} \mathrm{C}$ for $0.1 \mathrm{~min}$, increased at $13^{\circ} \mathrm{C} / \mathrm{min}$ to $140^{\circ} \mathrm{C}$, then at $8^{\circ} \mathrm{C} / \mathrm{min}$ to $180^{\circ} \mathrm{C}$ then increased at $5^{\circ} \mathrm{C} / \mathrm{min}$ to $220^{\circ} \mathrm{C}$ and then at $3^{\circ} \mathrm{C} / \mathrm{min}$ to $300^{\circ} \mathrm{C}$ held for 10 minutes. Injection volume was $2 \mu \mathrm{L}$ in splitless mode and the solvent delay was set to 5 minutes. The mass detector was operated in multiple reaction monitoring (MRM) mode using electron ionization (EI) source set at $70 \mathrm{eV}$ and argon as collision gas (1.5 bar). MS/MS parameters were optimized by injecting standard solutions, using full scan mode ( $\mathrm{m} / \mathrm{z}$ 50-650) on a first step to select precursor ions (Q1) that were later fragmented into product ions (Q3) testing different collision energies (CE) (from 10 to $30 \mathrm{eV}$ ). All the data were processed using the Xcalibur software. The noise type selected was the root mean square (RMS). The parameters of the multiresidue method are shown in Table 2. 
Table 2

Molecules, precursor, quantification and confirmation ions, the collision energy (CE), and retention times. 2 isomers of the compounds CYP, DELT, and PER. 


\begin{tabular}{|c|c|c|c|c|c|c|c|}
\hline Class & Molecule & $\begin{array}{l}\text { Retention } \\
\text { time (min) }\end{array}$ & $\begin{array}{l}\text { Precursor } \\
\text { ion }(\mathrm{m} / \mathrm{z})\end{array}$ & $\begin{array}{l}\mathrm{CE} \\
(\mathrm{ev})\end{array}$ & $\begin{array}{l}\text { Quantification } \\
\text { ion }(\mathrm{m} / \mathrm{z})\end{array}$ & $\begin{array}{l}\mathrm{CE} \\
\text { (ev) }\end{array}$ & $\begin{array}{l}\text { Confirmation } \\
\text { ion }(\mathrm{m} / \mathrm{z})\end{array}$ \\
\hline \multirow[t]{5}{*}{ UV Filters } & EHMC & 21.93 & 178 & 15 & 177 & 15 & 161 \\
\hline & EHS & 13.17 & 120 & 15 & 92 & 15 & 63 \\
\hline & OC & 28.75 & 248 & 25 & 165 & 25 & 220 \\
\hline & ODPABA & 21.00 & 165 & 15 & 164 & 15 & 118 \\
\hline & 4-MBC & 17.43 & 254 & 10 & 239 & 10 & 211 \\
\hline \multirow{2}{*}{$\begin{array}{l}\text { UV } \\
\text { stabilizers }\end{array}$} & UV-P & 17.66 & 225 & 20 & 168 & 20 & 196 \\
\hline & UV-326 & 26.59 & 300 & 15 & 119 & 15 & 191 \\
\hline \multirow[t]{5}{*}{ PCMs } & $\mathrm{HHCB}$ & 13.84 & 243 & 15 & 213 & 15 & 171 \\
\hline & $A D B I$ & 11.74 & 229 & 15 & 173 & 15 & 131 \\
\hline & OTNE & 11.13 & 191 & 15 & 121 & 15 & 93 \\
\hline & AHTN & 13.97 & 243 & 15 & 159 & 15 & 187 \\
\hline & DPMI & 11.13 & 191 & 15 & 135 & 15 & 107 \\
\hline \multirow[t]{4}{*}{ Pyrethroids } & BIF & 24.87 & 181 & 10 & 166 & 10 & 165 \\
\hline & CYP & $32.26 ; 32.73$ & 163 & 10 & 91 & 10 & 127 \\
\hline & Delt & $36.60 ; 37.19$ & 253 & 10 & 174 & 10 & 172 \\
\hline & PER & $29.71 ; 30.09$ & 183 & 15 & 168 & 15 & 153 \\
\hline \multirow[t]{2}{*}{ Biocides } & Irgarol & 17.52 & 253 & 15 & 196 & 15 & 182 \\
\hline & MTCS & 18.43 & 302 & 20 & 252 & 20 & 217 \\
\hline \multirow[t]{2}{*}{ Alkylphenols } & $4 n-N P$ & 14.26 & 107 & 25 & 77 & 25 & 95 \\
\hline & 4-t-OP & 10.22 & 135 & 15 & 107 & 15 & 77 \\
\hline \multirow[t]{9}{*}{ PAHs } & Naph & 5.15 & 128 & 20 & 102 & 20 & 126 \\
\hline & Acy & 8.43 & 152 & 28 & 150 & 28 & 126 \\
\hline & Ace & 8.86 & 153 & 25 & 152 & 25 & 151 \\
\hline & Flu & 10.21 & 165 & 30 & 163 & 30 & 164 \\
\hline & Phe & 13.15 & 178 & 30 & 176 & 30 & 152 \\
\hline & Ant & 13.35 & 178 & 30 & 176 & 30 & 152 \\
\hline & Flt & 17.71 & 202 & 30 & 200 & 30 & 201 \\
\hline & Pyr & 18.63 & 202 & 35 & 200 & 35 & 201 \\
\hline & $\mathrm{BaA}$ & 24.94 & 228 & 30 & 201 & 30 & 200 \\
\hline
\end{tabular}




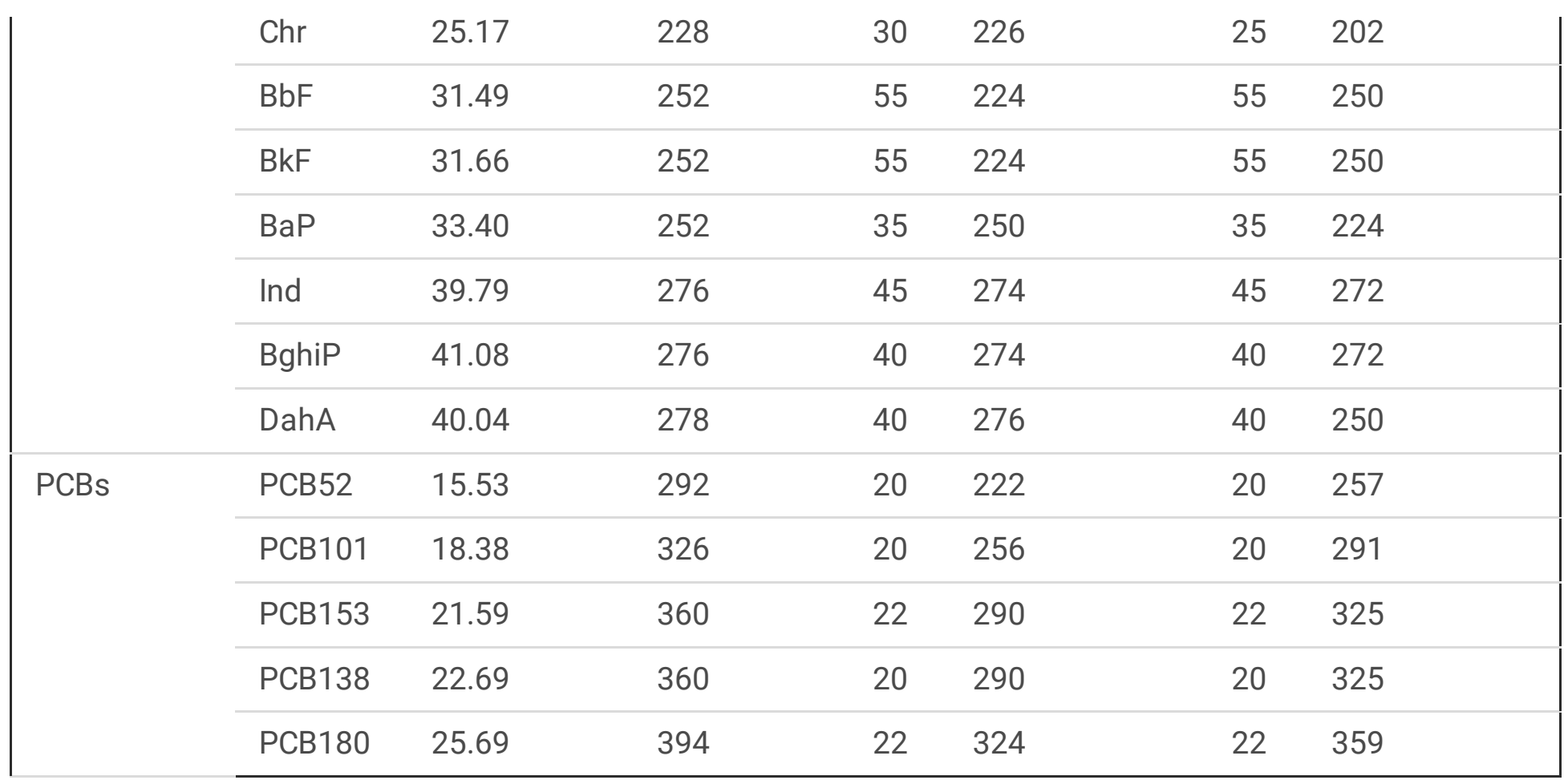

\section{Quality assurance/quality control}

Quality assurance/quality control procedures were applied to ensure that results are reliable. Method blanks (solvent) were extracted and analyzed as a control in the same way as the samples and no target compounds were detected in the blanks. A standard solution of target compounds was analyzed at the beginning and after each sample sequence to monitor the instrumental and potential contamination during GC-MS/MS detection.

Calibration curves were constructed in heptane for each compound in the range of 0-1000 ng/mL for PAHs and 0-100 ng/mL for the other compounds. Instrumental limits of detection (iLOD) and quantification (iLOQ) for each target compound were calculated based on the signal to noise ratio of 3 (iLOD) and a signal-to-noise ratio of 10 (iLOQs) near the target peak by using calibration curve solutions in the range of $0-50 \mathrm{ng} / \mathrm{mL}$. The method limits of detection (MDL) were estimated by multiplying the iLOD by the volume of the final extract of sediment $(1 \mathrm{~mL})$ and then dividing it by the mass of extracted sediments $(2 \mathrm{~g})$. The method limits of quantification (MQL) were estimated by multiplying the MDLs with a factor of 10/3. These parameters are reported in Table 3 .

The repeatability of the analysis method was studied by calculating the coefficients of variation obtained for 5 simultaneous extractions of the same sediment in identical conditions. The coefficients of variation for all the molecules were below $25 \%$ except for the (ADBI) (27\%). The recoveries of acenaphthene d10, phenanthrene d10, chrysene d12, 4-MBC d4 and 4n-NP-2,3,5,6-D4-OD were 126, 118, 115, 116 and $114 \%$ respectively.

The calculation of the matrix effects is essential to quantify molecules at trace levels in the environmental matrix. The matrix effects of the analytical method were evaluated using solvent and matrix-matched calibration curves. The matrix effects were negligible (between -20 and 20\%) for 11 compounds. However, the other molecules presented a high matrix effect (between -100 and 191\%). Due to these high matrix effects, the quantification of all analytes was done with matrix-matched calibration curves using five orders of magnitude $(2.5,12.5,25,50$, and $100 \mathrm{ng} / \mathrm{g}$ and up to $1000 \mathrm{for}$ PAHs). 
Table 3

Instrumental (pg) and method (ng/g dry weight) limits of detection and quantification of the target compounds. 


\begin{tabular}{|c|c|c|c|c|c|}
\hline Class & Molecule & iLOD (pg) & iLOQ (pg) & MDL(ng/g) & MQL(ng/g) \\
\hline \multirow[t]{5}{*}{ UV filters } & EHMC & 5.09 & 16.97 & 1.27 & 4.24 \\
\hline & EHS & 6.01 & 20.03 & 1.50 & 5.01 \\
\hline & $\mathrm{OC}$ & 7.94 & 26.47 & 1.99 & 6.62 \\
\hline & ODPABA & 4.74 & 15.80 & 1.19 & 3.95 \\
\hline & 4-MBC & 1.15 & 3.83 & 0.29 & 0.96 \\
\hline \multirow[t]{2}{*}{ UV stabilizers } & UV-P & 1.89 & 6.30 & 0.47 & 1.58 \\
\hline & UV-326 & 2.95 & 9.83 & 0.74 & 2.46 \\
\hline \multirow[t]{5}{*}{ Polycyclic musks } & HHCB & 2.00 & 6.67 & 0.50 & 1.67 \\
\hline & ADBI & 3.80 & 12.67 & 0.95 & 3.17 \\
\hline & OTNE & 10.65 & 35.50 & 2.66 & 8.88 \\
\hline & AHTN & 2.97 & 9.90 & 0.74 & 2.48 \\
\hline & DPMI & 9.35 & 31.17 & 2.34 & 7.79 \\
\hline \multirow[t]{4}{*}{ Pyrethroids } & BIF & 2.00 & 6.67 & 0.50 & 1.67 \\
\hline & CYP & 10.00 & 33.33 & 2.50 & 8.33 \\
\hline & DELT & 6.24 & 20.80 & 1.56 & 5.20 \\
\hline & PER & 32.23 & 107.43 & 8.06 & 26.86 \\
\hline \multirow[t]{2}{*}{ Biocides } & Irgarol & 0.20 & 0.67 & 0.05 & 0.17 \\
\hline & MTCS & 2.00 & 6.67 & 0.50 & 1.67 \\
\hline \multirow[t]{2}{*}{ APs } & 4n-NP & 6.20 & 20.67 & 1.55 & 5.17 \\
\hline & 4-t-OP & 1.50 & 5.00 & 0.38 & 1.25 \\
\hline \multirow[t]{10}{*}{ PAHs } & Naph & 0.84 & 2.80 & 0.21 & 0.70 \\
\hline & Acy & 1.51 & 5.03 & 0.38 & 1.26 \\
\hline & Ace & 0.43 & 1.43 & 0.11 & 0.36 \\
\hline & Flu & 1.21 & 4.03 & 0.30 & 1.01 \\
\hline & Phe & 2.00 & 6.67 & 0.50 & 1.67 \\
\hline & Ant & 2.17 & 7.23 & 0.54 & 1.81 \\
\hline & Flt & 1.53 & 5.10 & 0.38 & 1.28 \\
\hline & Pyr & 2.00 & 6.67 & 0.50 & 1.67 \\
\hline & $\mathrm{BaA}$ & 4.14 & 13.80 & 1.04 & 3.45 \\
\hline & Chr & 2.64 & 8.80 & 0.66 & 2.20 \\
\hline
\end{tabular}




\begin{tabular}{|llllll|}
\hline \multirow{4}{*}{ BbF } & 1.96 & 6.53 & 0.49 & 1.63 \\
\hline BkF & 1.41 & 4.70 & 0.35 & 1.18 \\
\hline BaP & 3.13 & 10.43 & 0.78 & 2.61 \\
\hline Ind & 2.00 & 6.67 & 0.50 & 1.67 \\
\hline PCBs & DahA & 2.16 & 7.20 & 0.54 & 1.80 \\
\hline BghiP & 4.00 & 13.33 & 1.00 & 3.33 \\
\hline PCB 52 & 0.88 & 2.93 & 0.22 & 0.73 \\
\hline PCB 101 & 0.80 & 2.67 & 0.20 & 0.67 \\
\hline PCB 153 & 0.54 & 1.80 & 0.14 & 0.45 \\
\hline PCB 138 & 0.87 & 2.90 & 0.22 & 0.73 \\
\hline PCB 180 & 0.40 & 1.33 & 0.10 & 0.33 \\
\hline
\end{tabular}

\section{Data treatment, statistics, and risk assessment}

Each sediment was extracted into two replicates then injected twice. Concentration values lower than MDL were treated as zero and concentrations values lower than MQL were replaced with the intermediate value between MDL and MQL.

All statistical analyses were performed with the software package SPSS (Statistical Package for Social Sciences) version 22.0. To assemble sites into homogeneous groups (DUU, RU, UD, and EST) based on the obtained concentrations of each class of contaminants, one-way analysis of variance ANOVA followed by a Tuckey's HSD and fishers LSD multiple comparison test (MCT) were conducted. To test for significant levels of differences between one sampling group of sites to another, one way ANOVA test was performed. Independent samples T-test was conducted to investigate differences between the two months' surveys (February and September). Differences were considered significant at $p$-value $<0.05$. Pearson correlation test was performed to evaluate the correlation between concentrations of each contaminant and total organic carbon (TOC) and fine particle size. Correlations between contaminants concentrations and TOC content in sediments were investigated to reveal if both legacy and emerging contaminants tend to accumulate in sediments of higher TOC content due to their lipophilic properties. Moreover, the Pearson correlation test was performed to evaluate the correlation between contaminant concentrations and population density for all the studied sites, to select molecules as markers of urbanization activities. The population density reported in Table 1 was used for Pearson correlation tests. Correlations were considered significant at $p$-value $<0.05$.

For identifying PAHs sources in the environment different ratio plots such as anthracene and phenanthrene (Ant/Ant + Phe), fluoranthene and pyrene (Flt/Flt + Pyr), and indeno[1,2,3-cd]pyrene and benzo[g,h,i]perylene (Ind/Ind + BghiP) (Yunker et al., 2002) were calculated when these molecules were found. The ratio of HHCB/AHTN as proposed by Zeng et al., (2008) was calculated as an indicator of differences in application and use in specific regions and as a tracer of their degradation and transformation during transport in aquatic systems. 
The evaluation of the potential risk was performed based on the hazard quotients (HQ). HQ were calculated for measured compounds with available ecotoxicological data, according to the United States Environmental Protection Agency (USEPA) by dividing the measured environmental concentration (MEC) obtained from this study for each sampling site by the predicted no effect concentration (PNEC) obtained from the literature. The references of PNEC values used for this manuscript are those reported by Pintado-Herrera et al., (2017a). The interpretation of the hazard quotients was followed as recommended by Wentsel et al., (1996): HQ < 1 indicates that the compound has no ecological risk; $1 \leq \mathrm{HQ}<10$ indicates small potential risk; $10 \leq \mathrm{HQ}<100$ indicates significant potential adverse effects and $\mathrm{HQ} \geq 100$ indicates adverse effects. The total $\mathrm{HQ}$ of emerging compounds $(\Sigma \mathrm{HQ})$, was calculated by adding $\mathrm{HQ}$ of every emerging contaminant for every sampling site. Similarly, total HQ of legacy contaminants ( $(\mathrm{HQ})$ was calculated by summing up HQ of PCBs, PAHs with low molecular weight (LPAHs), and PAHs with high molecular weight (HPAHs) for every sampling site. This additive model is used to evaluate the ecotoxicological risk posed by each group of the studied contaminants in each of the four sampling areas (RU, DUU, UD, and EST areas). However, this method does not take into consideration unpredictable synergism or antagonism effects of compounds (Cristale et al., 2013).

\section{Results}

\section{Occurrence and distribution of contaminants}

Frequencies of detection and concentration ranges of the studied compounds are presented in Table 4 . All the compounds were detected at frequencies ranging from $100 \%$ for PAHs and PCBs to higher than 70\%, except for two pyrethroids BIF $65 \%$ and DELT $47 \%$. Concentrations of emerging contaminants varied from not detected to $94.22 \mathrm{ng} / \mathrm{g}$ d.w. (DPMI). The total PAHs concentration calculated as the addition of the 16 studied PAHs ranged from 53.49 to $311.79 \mathrm{ng} / \mathrm{g}$ d.w. and the total PCBs concentration calculated as the addition of PCB 52, PCB 101, PCB 153, PCB 138, and PCB 180 ranged from $0.91 \mathrm{ng} / \mathrm{g}$ to $11.11 \mathrm{ng} / \mathrm{g}$ d.w.

Table 4

Concentration profiles (range, mean \pm standard deviation (SD) and detection frequencies (d.f \%)) of the studied compounds in sediment samples of the Kadicha river. Range concentrations are in ng of dry weight (d.w.) 


\begin{tabular}{|c|c|c|c|c|}
\hline Class & Compound & Range (ng/g) & Mean $\pm S D$ & d.f $\%$ \\
\hline \multirow[t]{5}{*}{ UVFs } & EHMC & $<$ MDL-42.67 & $13.38 \pm 5.22$ & $95 \%$ \\
\hline & EHS & $<M D L-14.42$ & $7.87 \pm 5.00$ & $91 \%$ \\
\hline & $\mathrm{OC}$ & $<M D L-75.70$ & $23.11 \pm 5.78$ & $95 \%$ \\
\hline & ODPABA & $<M Q L-21.29$ & $<M Q L$ & $71 \%$ \\
\hline & $4-\mathrm{MBC}$ & $<$ MQL-21.29 & $9.49 \pm 3.89$ & $100 \%$ \\
\hline \multirow[t]{2}{*}{ UVSs } & UV-P & $<M D L-4.56$ & $<M Q L$ & $96 \%$ \\
\hline & UV-326 & $<M D L-30.52$ & $8.34 \pm 3.29$ & $91 \%$ \\
\hline \multirow[t]{5}{*}{ PCMs } & $\mathrm{HHCB}$ & $<$ MDL-81.13 & $25.09 \pm 7.02$ & $94 \%$ \\
\hline & $\mathrm{ADBI}$ & $<M D L-4.35$ & $<M Q L$ & $70 \%$ \\
\hline & OTNE & $<$ MDL-74.09 & $41.61 \pm 12.01$ & $94 \%$ \\
\hline & AHTN & $<M D L-64.58$ & $19.77 \pm 7.40$ & $96 \%$ \\
\hline & DPMI & $<$ MDL-94.22 & $47.54 \pm 13.42$ & $94 \%$ \\
\hline \multirow[t]{4}{*}{ Pyrethroids } & BIF & $<M D L-18.86$ & $3.08 \pm 1.77$ & $65 \%$ \\
\hline & CYP & $<M D L-44.75$ & $15.44 \pm 5.54$ & $94 \%$ \\
\hline & DELT & $<$ MDL-13.38 & $<M Q L$ & $47 \%$ \\
\hline & PER & $<M D L-42.22$ & $<M Q L$ & $73 \%$ \\
\hline \multirow[t]{2}{*}{ Biocides } & Irgarol & $<M D L-1.75$ & $0.66 \pm 0.52$ & $96 \%$ \\
\hline & MTCS & $<M D L-43.63$ & $6.17 \pm 1.67$ & $86 \%$ \\
\hline \multirow[t]{2}{*}{ APs } & $4 n-N P$ & $<M D L-9.26$ & $4.28 \pm 3.4$ & $90 \%$ \\
\hline & $4-\mathrm{t}-\mathrm{OP}$ & $2-27.91$ & $12.40 \pm 5.25$ & $100 \%$ \\
\hline PAHs & $\triangle 16 \mathrm{PAHs}$ & $53.49-311.79$ & $139.69 \pm 41.5$ & $100 \%$ \\
\hline PCBs & $\triangle 5$ PCBs & $0.91-11.11$ & $3.49 \pm 1.58$ & $100 \%$ \\
\hline
\end{tabular}

The distribution pattern within each class of contaminants occurring in the different areas (RU, DUU, UD, and EST) is shown in Figure 2 for the month of February. The profile is similar in September except for pesticides. UVFs and UVSs showed a quite homogenous distribution within DUU, UD and EST areas, with OC accounting for almost $40 \%$ of the total substances whereas $4-\mathrm{MBC}$ accounted for almost $38 \%$ of the RU area. Among PCMs, DPMI showed the highest percentages, accounting for $34 \%$ of the studied areas except for DUU, where AHTN was found at the highest concentration. The distribution pattern of pesticides in February showed a strong contrast between the DUU and RU areas, where PER and CYP showed the highest percent, respectively. CYP accounts for $90 \%$ of the pesticides in the RU area and PER accounts for $87 \%$ in the DUU area. These two 
pesticides showed equivalent concentrations downstream of the river (UD and EST). In September, PER and CYP were the pesticides found at the highest concentration for the four areas. CYP accounts from $21 \%$ in the UD area to $40 \%$ in the DUU area. PER accounts from $36 \%$ in the DUU area to $66 \%$ in the UD area. The contribution of irgarol to the total pesticides was low $(\leq 10 \%)$. Based on their chemical composition, PAHs were divided into 2 groups including low molecular weight compounds (LPAHs) with 2 or 3 aromatic rings and high molecular weight compounds (HPAHs) with 4, 5, or 6 aromatic rings (García-Falcón et al., 2006). HPAHs with 4 aromatic rings (Flt, Pyr, BaA, and Chr) were dominant in the entire study area accounting for almost $37 \%$ of the total PAHs. Among PCBs, congeners of 4, 5, 6, and 7 chlorines were ubiquitous in the Kadicha river basin.

The total concentrations of each class of contaminants within the four studied areas are presented in Figure 3. PAHs and PCMs exhibited the highest concentrations, up to $270 \mathrm{ng} / \mathrm{g} \mathrm{d}$.w. and $169 \mathrm{ng} / \mathrm{g} \mathrm{d.w}$. respectively. The concentration profiles of the studied classes of contaminants have shown quite similar decreasing gradients within the four areas of the river basin, as follows: EST > DUU > UD > RU. The exception to this rule appears occasionally, with non-significant differences between two of the four areas (except for PCMs between EST and DUU areas in September). An example of the evolution of individual contaminant concentrations within each class is shown in Figure 4.

The ratio of PCMs HHCB/AHTN ranged from 0.61 to 3.63 (with a mean of 2.08). In all sampling sites, the ratio is higher than 1, except for the site Ks during the wet season (0.61) indicating higher concentrations of HHCB in sediments. PAH ratios (Figure S) showed the majority of the samples in the petroleum combustion region indicating pyrolytic sources of PAHs.

The correlation between population density and the levels of occurrence of each class of contaminants was studied to understand whether these contaminants can be selected as urbanization markers in this watershed. The results show a significant correlation for PER $\left(r^{2}=0.772 ; p\right.$-value=0.025), HHCB $\left(r^{2}=0.689 ; p-v a l u e=0.009\right)$, UV-326 $\left(r^{2}=0.592 ; p-v a l u e=0.033\right)$ and the total PAHs $\left(r^{2}=0.515 ; p\right.$-value=0.012) with the population density. However, the population density value used is derived from estimation and further studies should be carried out to use this variable in explaining sediment contamination.

Total organic carbon (TOC) content in sediment samples ranged from 1.64 to $5.47 \%$ during the wet season survey and from 1.77 to $7.14 \%$ during the dry season survey. The percentage of fine particles $(<63 \mu \mathrm{m})$ and TOC content in sediments of the studied sites for the 2 studied campaigns are shown in Table S1. It is interesting to note that Pearson correlation analysis showed no correlation between the percentage of fine particles and any of the studied compounds. For TOC content in sediments, no correlation was found with concentrations of UVFs, UVSs, PCMs, APs, and PCBs. Among emerging contaminants, only BIF ( $r^{2}=0.871$; $p$-value=0.05), DELT ( $r^{2}=0.727$; $p$-value=0.041) and MTCS $\left(r^{2}=0.729 ; p\right.$-value=0.040) showed significant correlation with TOC content. Among legacy contaminants the total PAHs showed significant correlations with TOC content in sediments $\left(r^{2}=0.423 ; p-\right.$ value=0.044).

\section{Risk assessment}

The hazard quotients (HQ) were calculated for compounds with available ecotoxicology data on benthic species (8 emerging contaminants and all legacy contaminants). T-tests were conducted to investigate differences 
between the HQ values calculated for the two months' surveys (February and September). Differences between the two months' surveys were not significant, thus $\mathrm{HQ}$ values corresponding to the month of February were interpreted. The values of HQs for individual compounds at every sampling site are shown in Table S2.

For emerging contaminants, $\mathrm{HQ}$ values for EHMC and 4-MBC were higher than 1 for the majority of the studied sites exhibiting values up to 11.3 (within the site EAA-2) and 7.1 (within the site Ar) respectively. However, HQ values for the other emerging contaminants were lower than 1 within all the studied sites. For legacy contaminants, the hazard quotient was calculated for the sum of PCBs, the sum of PAHs with low molecular weight (LPAHs), and the sum of PAHs with high molecular weight (HPAHs). HQs for Legacy contaminants were found to be higher than 1 at all sampling sites: HQs for LPAHs were the highest on the majority of the studied sites (>10) followed by PCBs achieving a maximum value at site EAA-2 (31.1) within the estuary area.

The spatial distribution of $\triangle \mathrm{HQ}$ s of legacy and emerging contaminants in the Kadicha river basin are shown in Figure 5. It is important to note that the sum of hazard quotients is not a quantitative measurement but a way to illustrate the spatial distribution of both groups of contaminants at each sampling area. The distribution of HQs among the four different areas is similar to the distribution of the concentration of most legacy and emerging contaminants in sediment. It is clear that HQs for legacy contaminants are significantly higher than for emerging contaminants. Regardless of the group of contaminants, the estuary area shows the highest $\triangle \mathrm{HQ}$ s, while the rural upstream area shows the lowest $\triangle \mathrm{HQ}$ s. This suggests that the estuary presents the highest potential risks while the rural upstream area shows the lowest potential risks for benthic species.

\section{Discussions}

\section{Occurrence, distribution, and sources of legacy and emerging contaminants}

The anthropogenic pressures currently exerted within the small Mediterranean river watersheds are well represented in the Kadicha river with high human pressure along the river. The discontinuous dwelling place observed in the mountainous rural areas becomes denser in the downstream part of the river with the densely urbanized area in the estuary. Higher anthropogenic pressure is reflected in higher sediment contamination in more densely populated areas. The discharge of leachates and non-treated wastewater effluents from urban areas contributed to the highest concentrations of UVFs, UVSs and PCMs obtained in the estuary and also within DUU independently of the season. HHCB and UV-236 concentrations then appeared correlated significantly with population density and might represent promising markers of human activities in future studies within the watershed. Among the anthropogenic pressures, pesticides are used in general as markers of agricultural activities. We selected pyrethroids instead of other pesticides groups because of their important use in mosquito control by residential of the urban area during the summer season. Consequently, concentrations of pyrethroids during September's survey were higher than during February's survey. Moreover, contamination of sediments from the discontinuous urbanized upstream was higher than the other groups of sites. These findings suggest that the mixed land use, combining agricultural, urban and residential zones can be considered as the prominent source of insecticide contamination in the Kadicha river basin. Among pyrethroids, PER can be used as a marker of human activities due to its correlation with population density. On the opposite, the low levels of 
concentrations of irgarol, used as a booster biocide added to antifouling paints (Thomas et al., 2002), measured in the river sediments can be explained by the absence of boat activity within the river.

Alkylphenols are products of degradation of polyethoxylated alkylphenols (Giger et al., 1984) used in industrial products and pesticide mixtures. The occurrence of these compounds is already studied in Lebanon with concentrations of a mixture of nonylphenol isomers ranging from 145 to $2022 \mathrm{ng} / \mathrm{g}$ d.w. within the downstream of the Kadicha river (Amine et al., 2018b). The concentrations of individuals 4n-NP and 4-t-OP measured in the present work confirmed sediment contamination. PAHs and PCBs are markers of anthropogenic activities trapped in sediments. Their increase within the estuary zone observed in the two campaigns can be explained by the deposition of the fine grain particles at the river-sea boundary zone due to the mixing process of fresh and saline water (Chen et al., 2006; Pintado-Herrera et al., 2017b) and the increase of anthropogenic pressure in the downstream part of the river. Indeed, the percentage of fine particles in the estuary zone with a diameter lower than $63 \mu \mathrm{m}$ is higher than the other groups of sites (Table S1). In general, LPAHs are derived from oil and fuel spills while high molecular weight compounds are generated from combustion processes (Souza et al., 2018). The predominance of HPAHs can indicate the presence of combustion products from pyrolytic sources (coal, biomass combustion, or traffic) (Yunker et al., 2002) in the Kadicha river basin. The water solubility and lower stability of LPAHs towards biodegradation (Quantin et al., 2005; Nguyen et al., 2014; Zhang et al., 2016) may be an additional cause for the predominance of HPAHs in this watershed. Moreover, the ratio plots of PAHs congeners indicate a pyrolytic source of PAHs. These findings indicate that the Kadicha river basin is mainly affected by continental activities which may be associated with vehicle traffic and power generators around the studied areas. PAHs concentrations appeared to be correlated with population density, thus these molecules can be selected as markers of human pressures in this watershed.

\section{Fate in the aquatic environment: legacy vs. emerging contaminants}

The presence of the legacy and emerging contaminants in the Kadicha river is due to anthropogenic pressures discussed previously and depends on the fate of these contaminants in sediment. Half-lives of legacy and emerging contaminants reported from the literature are summarized in Table S3. The half-lives of the studied PAHs in anaerobic soil reported from the literature range between 124 (Phe) and 455 days (BghiP) (Table S3) (except for Naph, Ace, and Flu with half-lives $<65$ days). After their deposition in sediments, PAHs are less subjected to photochemical or biological oxidation, especially in anoxic sediment (Nemr et al., 2007). Thus, PAHs tend to be persistent in sediments, where they may accumulate at high concentrations (Witt, 1995). This can explain their correlation with TOC content in the studied sediments. The biodegradation of PCBs was reported to be very slow in sediments with half-lives between 3650 days (PCB 52) and 13750 days (PCB 180) (Beurskens et al., 1993; Sinkkonen and Paasivirta, 2000; Magar et al., 2005). In this study, PCBs concentrations did not show a correlation with TOC content. Our findings are in accordance with the study of (Vane et al., 2007). The correlation PCBs-TOC can be discriminated by other geochemical processes such as sediment composition of organic matter that may play a greater role than TOC content (Landrum and Faust, 1991; Vane et al., 2007). The half-lives of the studied emerging contaminants were shorter and ranged between 1.9 (AHTN) and 141 days (UV-326) except for BIF (425 days), PER (197 days), and MTC (443 days). This suggests that biodegradation processes for the majority of emerging contaminants except the aforementioned compounds can occur in

Page 18/35 
sediments more easily than for legacy contaminants. However, the biodegradation processes should be interpreted with caution as the half-lives of contaminants can differ from a matrix to another.

While biodegradation of legacy contaminants has been studied for decades, there is a lack of studies on the biodegradation of emerging contaminants in soils and sediments, and these molecules need to be more studied to understand their fate in the environment.

\section{Ecotoxicological implications}

The lipophilicity of the studied compounds enhances their accumulation in sediments and as a consequence their accumulation in benthic species (Vimalkumar et al., 2018). It has been reported that the ecological risk of highly lipophilic chemicals (Kow>5) tends to be amplified through bioaccumulation and trophic transfer (Tang et al., 2018). Indeed, chemicals (EHMC, 4-MBC, PCBs, and PAHs) that have shown potential risks in this study $(\mathrm{HQ}>1)$ have an octanol-water partition coefficient higher than five. Therefore, they may pose adverse effects on aquatic species through the diet. The adverse effects of ultraviolet filters on the growth of different aquatic species (e.g, the crustacean Daphnia magna and the dipteran Chironomus riparius) has been reported in the literature (Sieratowicz et al., 2011; Campos et al., 2017). Moreover, these compounds are endocrine disruptors that can alter estrogenic and hormonal activity in fish (Kunz and Fent, 2006; Kunz et al., 2006; Wang et al., 2016) and in invertebrates (Campos et al., 2017). Exposure to EHMC can decrease the length of Daphnia magna species and cause a toxic effect on the reproduction of snails Potamopyrgus antipodarum and Melanoides tuberculata (Sieratowicz et al., 2011; Kaiser et al., 2012). Exposure to 4-MBC has been shown to cause deleterious effects in freshwater organisms (Brausch and Rand, 2011). Moreover, it can influence the neurotransmission process mediated by acetylcholine through the inhibition of acetylcholinesterase in zebrafish (Torres, 2013).

The main adverse effect of PAHs on invertebrates is narcosis that can be responsible for the cell membrane function alteration causing mild toxic effects or mortality (Burgess, 2009; Maletić et al., 2019). The toxicity of PAHs to aquatic organisms can be affected by its metabolism and photooxidation (Abdel-Shafy and Mansour, 2016). Parental compounds and their metabolic breakdown in tissues of aquatic organisms can be toxic (Logan, 2007). They become more toxic in the presence of ultraviolet light (Abdel-Shafy and Mansour, 2016). Adverse effects of PAHs on exposed fish are widely reported in the literature (Corrales et al., 2014; Vignet et al., 2014; Sun et al., 2015). The main adverse effects of PAHs are narcosis, mortality, decrease in growth, lower condition factor, and damage to immune systems (Logan, 2007). The toxicity of PCBs to shrimps and amphipods has been proven (Ho et al., 1997). Zeng et al., (2003) found that contaminated sediments with PCBs inhibited sea urchin growth. Therefore, both benthic and aquatic species in the Kadicha river basin may be subject to adverse effects caused by the presence of emerging (EHMC and 4-MBC) and legacy contaminants (PAHs and PCBs) in riverine sediments.

Information about ecotoxicological risk derived from the co-occurrence of both groups of contaminants in Mediterranean rivers is very scarce. Our results do not show consistency with the results of Köck-Schulmeyer et al., (2021) who found that emerging contaminants were the major contributors of potential risk in Adige and Sava river basins. 


\section{Local and international context}

In Lebanon, if there is some data on legacy contaminants, there is a lack of research on emerging contaminants (Tables S4, S5, S6, S7, and S8). Only one study has been conducted on the occurrence of UV filters (EHMC, OC, and ODPABA) in river sediments (Amine et al., 2012) while no studies have been conducted on UV stabilizers in Lebanese river waters. Among UV filters, the concentrations of EHMC and OC were in the same range of the previous study of Amine et al., (2012) conducted on the estuary of the Kadicha river (Table S4). Whereas the concentration of ODPABA was slightly lower in the present study. Moreover, the ubiquity of $\mathrm{OC}$ in the present study is in accordance with the study of (Amine et al., 2012) which is probably due to its wide usage in personal care products and cosmetics (ECHA, 2019). The predominance of OC in the estuary area can also be explained by its multiple sources: OC can occur due to direct discharge of the leachates in the estuary. In addition to its point source, OC is highly stable to photodegradation (Rodil and Moeder, 2008) and can undergo long-range transport (Tsui et al., 2014) from the upstream areas. The occurrence of EHMC and OC in freshwater sediments was the most studied among other UV filters. However, few studies report the concentrations of EHS and UV stabilizers in freshwater sediments. Among the data collected from the literature regarding the worldwide occurrence of UV filters and stabilizers, sediments from Ebro river in Spain and Pearl river and its estuary in China (Gago-Ferrero et al., 2011; Peng et al., 2017; Pintado-Herrera et al., 2017b), influenced by industrial activities, showed high concentrations of UVFs and UVSs. Levels of these compounds were lower in the present study. However, the concentrations of EHMC were in the same range of those found in the Ebro river basin in Spain (Gago-Ferrero et al., 2011).

No studies were conducted on the occurrence of fragrances in Lebanese rivers. Among polycyclic musks, HHCB and AHTN were the most studied in riverine sediments (Table S5) probably because they represent $95 \%$ of the European market of polycyclic musks and nitromusks (OSPAR Commission, 2004). Thus, they are incremented to be present at elevated levels in sediments. Fewer studies have analyzed ADBI, OTNE, and DPMI in riverine sediments. High levels of PCMs were observed in sediments from Pearl River and its estuary in China dominated by industrial activities (Pintado-Herrera et al., 2017b, Zeng et al., 2018b). Moreover, high levels of PCMs were present in Molgora river in Italy (Villa et al., 2012). These high levels can be explained by the heavy use of PCMs in Italy (Villa et al., 2012). These compounds were present at lower levels in Kadicha river basin, except for DPMI detected at higher levels (up to $94 \mathrm{ng} / \mathrm{g}$ ). The ubiquity of DPMI in the present study is not consistent with these reported by Zeng et al., (2018a) who quantified DPMI in sediments from one sampling site on the downstream of Hun river in the northeast of China while AHTN and HHCB were the most prominent fragrances. Neither with the study of Pintado-Herrera et al., (2017b) where the mean concentrations of HHCB, AHTN, and DPMI was at the same level, while the mean concentration of the OTNE exhibited the highest mean concentration among the studied fragrances in sediments from the Pearl River estuary in China. Or with the study of Pintado-Herrera et al., (2017a) who found that DPMI and ADBI were the fragrances with the lowest concentrations among 5 studied compounds (HHCB, ADBI, OTNE, AHTN, and DPMI) in coastal sediments from the Cadiz Bay in Spain while the HHCB was the predominant contaminant. This difference can be due to the preference of usage of fragrances by country.

The majority of the studies regarding the occurrence of pyrethroids were conducted in the USA and China (Table S6). Thus, there is a lack of studies conducted within the Mediterranean basin region concerning these contaminants. This is a novelty for the present study. In Lebanon, two studies were conducted on the occurrence 
of bifenthrin in riverine surface water samples, groundwater, and drinking water (Kouzayha et al., 2013; Youssef et al., 2015). High concentrations of pyrethroids were found in sediments from Nhue and Lich rivers in Vietnam (Duong et al., 2014) influenced by industrial and urban activities and the Santa Maria river and Oso Flako creek in the United States (Phillips et al., 2012) affected by urban and agricultural activities. Lower concentrations of pyrethroids were found in the Kadicha river basin. However, similar levels were reported in urban wetlands in Australia (Allinson et al., 2015) and Ballona creek in California (Chinen et al., 2016) dominated by urban activities and the Ebro river in Spain (Feo et al., 2010) influenced by agricultural activities. Therefore, mixture land uses with industrial activities seem to show higher concentrations than solely urban or agricultural land uses. Moreover, the ubiquity of CYP in this study is in accordance with the study of Li et al., (2011) where this compound was predominant among nine studied pyrethroids (bifenthrin, cyfluthrin, lamda-cyhalothrin, cypermethrin, deltamethrin, esfenvalerate, fenpropathrin, permethrin, and tefluthrin) accounting for more than $70 \%$ of the total pyrethroid concentrations within the Pearl River Delta in China.

There are numerous studies conducted in Lebanon on legacy contaminants. The levels of PAHs found in this study were in the same range of concentration as those found in riverine sediments from El Kebir, El Bared, and Kadicha rivers (Amine et al., 2018a) (Table S7). However, they were lower than in coastal sediments collected from urbanized cities (Tripoli, Jounieh, Dora, and Tyr) (Manneh et al., 2016) and Tripoli harbor (Merhaby et al., 2015) and in soil collected from different cities (Soukarieh et al., 2018). Similarly, the levels of PCBs found in the present study were more comparable to riverine sediments from the El Kebir river (Thomas et al., 2005) and lower than those found in coastal sediments from Tripoli harbor (Merhaby et al., 2015) (Table S8). The global comparison of PAHs levels shows lower concentration found in this study than rivers in China (Xu et al., 2016; Huang et al., 2017), Malaysia (Keshavarzifard et al., 2014), Taiwan (Tu et al., 2018), France (Kanzari et al., 2014; Net et al., 2015), Spain (Navarro et al., 2010), Germany (Liu et al., 2013) and Australia (Liu et al., 2017). For PCBs, lower concentrations found in this study from levels found in Haihe, Kaifaqu, Dagu, and Yongdingxin rivers, China (Liu et al., 2007), Huveaune river, France (Kanzari et al., 2014), and Niagara river, United States (Samara et al., 2006). This suggests that highly urbanized and industrialized areas show higher levels of PAHs and PCBs concentrations. The global comparison of the occurrence of emerging and legacy contaminants can suggest that our results are lower than sites highly urbanized affected by industrial activities.

\section{Conclusions}

The present work is the first study to assess the distribution of both legacy and emerging contaminants in a Lebanese watershed. All of the studied compounds were detected in sediments with legacy contaminants detected more frequently than emerging contaminants. Both groups of contaminants showed an increase of concentrations from the upstream to the downstream of the river associated with greater anthropogenic pressures. Different anthropogenic sources of contamination could be identified: contamination with UVF, UVSs, and PCMs was linked to direct discharge of raw wastewaters and leachates in the water body while contamination with pyrethroids and PAHs were related to pest control and vehicle traffic respectively. Moreover, several molecules (PAHs, PER, HHCB, and UV-326) have shown a significant correlation with population density and might represent promising markers of human activities in future studies within this watershed. Biodegradation of emerging contaminants in sediments could occur more easily than for legacy compounds. The most elevated potential risk for benthic species was observed within the estuary area. Anthropogenic activity in this highly urbanized area contributed to the observed levels of contamination, combined with the lack

Page 21/35 
of actual treatment of the wastewater produced. Moreover, several emerging and all the studied legacy compounds may pose adverse effects for both benthic and aquatic species in the Kadicha river basin. In general, concentrations of the studied contaminants did not exceed concentrations found in the literature and were lower than levels found in highly urbanized and industrial sites.

As all of the studied compounds were detected in this watershed, monitoring programs of these compounds are encouraged specifically within the urbanized areas of the river to make future public policies on water quality in Lebanon. Moreover, significant efforts should be made to collect and treat wastewater in this watershed to improve the situation of the coastal environment receiving these waters. The assessment of organic contaminants within this watershed may help to understand the potential contribution of this small Mediterranean river to the contamination of the coastal area.

\section{Declarations}

\section{Acknowledgments}

The authors would like to thank the platform of physico-chemical analyses of Ecolab laboratory within the University of Toulouse III Paul Sabatier for their facility use and technical support for particle-size distribution analyses in sediments. The authors would like to thank Adrien Chouchou (faculty of pharmacy, University of Montpellier) for his great help in revising the data for this manuscript. The authors wish to acknowledge the laboratory staff of Hydrosciences, namely Abdel Znidah, for the contribution to the sample preparation. The authors are also grateful for the help of Mohamad Merheb (faculty of public health, Lebanese University) in preparing the sampling map for this manuscript.

\section{Funding}

The authors would like to acknowledge the National Council for Scientific Research of Lebanon (CNRS-L), the University of Montpellier, and the Agence Universitaire de la Francophonie (AUF) for granting a doctoral fellowship to Fatmé Merhabi.

\section{Authors' contributions}

F.M: GC analysis, data processing, and manuscript writing E.G: study supervision, experimental design, and manuscript writing, H.A: sample treatment and preparation, D.R: sample treatment and preparation, J.H: methodology design for sampling strategy, H.F: Experimental design and manuscript writing.

Declarations

\section{Ethics approval and consent to participate}

Not applicable 


\section{Consent for publication}

Not applicable

\section{Availability of data and materials}

The datasets used during the current study are available from the corresponding author on reasonable request.

\section{Competing interests}

The authors declare that they have no competing interests.

\section{References}

1. Abdel-Shafy, H.I., Mansour, M.S.M., 2016. A review on polycyclic aromatic hydrocarbons: Source, environmental impact, effect on human health and remediation. Egypt. J. Pet. 25, 107-123. https://doi.org/10.1016/j.ejpe.2015.03.011

2. Abril, G., Nogueira, M., Etcheber, H., Cabeçadas, G., Lemaire, E., Brogueira, M.J., 2002. Behaviour of organic carbon in nine contrasting European estuaries. Estuar. Coast. Shelf Sci. 54, 241-262. https://doi.org/10.1006/ecss.2001.0844

3. AEMS, 2017. The impact of The syrian crisis on the lebanese power sector and priority recommendations. http://www.aems- Ib.com. Accessed 07 October 2018

4. Allinson, G., Zhang, P., Bui, A.D., Allinson, M., Rose, G., Marshall, S., Pettigrove, V., 2015. Pesticide and trace metal occurrence and aquatic benchmark exceedances in surface waters and sediments of urban wetlands and retention ponds in Melbourne, Australia. Environ. Sci. Pollut. Res. 22, 10214-10226.

https://doi.org/10.1007/s11356-015-4206-3

5. Amine, H., Gomez, E., Halwani, J., Casellas, C., Fenet, H., 2012. UV filters, ethylhexyl methoxycinnamate, octocrylene and ethylhexyl dimethyl PABA from untreated wastewater in sediment from eastern Mediterranean river transition and coastal zones. Mar. Pollut. Bull. 64, 2435-2442. https://doi.org/10.1016/j.marpolbul.2012.07.051

6. Amine, H., Halwani, J., Gomez, E., Merhabi, F., 2018a. Study of the contamination with polycyclic aromatic hydrocarbons in sediments and waters in northern Lebanon: Rivers, transition zones and port sites. Leban. Sci. J. 19, 343-372. https://doi.org/10.22453/LSJ-019.3.343372 (in French)

7. Amine, H., Merhabi, F., Halwani, J., Rosain, D., Casellas, C., Fenet, H., Gomez, E., 2018b. Alkylphenols and Alkylphenol Polyethoxylates levels in a Mediterranean developing country context: contamination of rivers and coastal sediments. Res. J. Chem. Environ. Sci. 6, 21-33. https://doi.org/www.aelsindia.com/rjces.htm

8. AQUAREF, 2016. Sediment sampling operations in continental environments (streams and water bodies) as part of the Water Frame Directive (WFD) monitoring programs - Technical recommendations. https://www.aquaref.fr/system/files/2016_Guide_Echantillonnage_CE_VF_2.pdf. Accessed 14 January 2019 (in French) 
9. Balázs, A., Krifaton, C., Orosz, I., Szoboszlay, S., Kovács, R., Csenki, Z., Urbányi, B., Kriszt, B., 2016. Hormonal activity, cytotoxicity and developmental toxicity of UV filters. Ecotoxicol. Environ. Saf. 131, 45-53. https://doi.org/10.1016/j.ecoenv.2016.04.037

10. Barbosa, A.E., Fernandes, J.N., David, L.M., 2012. Key issues for sustainable urban stormwater management. Water Res. 46, 6787-6798. https://doi.org/10.1016/j.watres.2012.05.029

11. Beurskens, J.E.M., Ge, M., Mol, A.J., Barreveld, H.L., Munstert, B. Van, Winkelss, H.J., 1993. Geochronology of priority pollutants in a sedimentation area of the Rhine river. Environmenlal Toxicol. Chem. 12, 1549-1566.

12. Brausch, J.M., Rand, G.M., 2011. A review of personal care products in the aquatic environment: Environmental concentrations and toxicity. Chemosphere 82, 1518-1532. https://doi.org/10.1016/j.chemosphere.2010.11.018

13. Burgess, R.M., 2009. Evaluating ecological risk to invertebrate receptors from PAHs in sediments at hazardous waste sites. U.S. Environmental Protection Agency, Ecological Risk Assessment Support Center, Cincinnati, OH.EPA/600/R-06/162. https://cfpub.epa.gov/si/si_public_record_report.cfm? dirEntryld=214715\&Lab=NCEA. Accessed 04 October 2019

14. Campos, D., Gravato, C., Fedorova, G., Burkina, V., Soares, A.M.V.M., Pestana, J.L.T., 2017. Ecotoxicity of two organic UV-filters to the freshwater caddisfly Sericostoma vittatum. Environ. Pollut. 228, 370-377. https://doi.org/10.1016/j.envpol.2017.05.021

15. Chalányová, M., Paulechová, M., Hutta, M., 2006. Method of analysis of a selected group of pyrethroids in soil samples using off-line flow-through extraction and on-column direct large-volume injection in reversed phase high performance liquid chromatography. J. Sep. Sci. 29, 2149-2157. https://doi.org/10.1002/jssc.200600013

16. Chen, S.J., Luo, X.J., Mai, B.X., Sheng, G.Y., Fu, J.M., Zeng, E.Y., 2006. Distribution and mass inventories of polycyclic aromatic hydrocarbons and organochlorine pesticides in sediments of the pearl river estuary and the northern South China Sea. Environ. Sci. Technol. 40, 709-714. https://doi.org/10.1021/es052060g

17. Chinen, K., Lau, S.L., Nonezyan, M., McElroy, E., Wolfe, B., Suffet, I.H., Stenstrom, M.K., 2016. Predicting runoff induced mass loads in urban watersheds: Linking land use and pyrethroid contamination. Water Res. 102, 607-618. https://doi.org/10.1016/j.watres.2016.06.040

18. Cooper, S.D., Lake, P.S., Sabater, S., Melack, J.M., Sabo, J.L., 2013. The effects of land use changes on streams and rivers in mediterranean climates. Hydrobiologia 719, 383-425.

https://doi.org/10.1007/s10750-012-1333-4

19. Corrales, J., Thornton, C., White, M., Willett, K.L., 2014. Multigenerational effects of benzo[a]pyrene exposure on survival and developmental deformities in zebrafish larvae. Aquat. Toxicol. 148, 16-26. https://doi.org/10.1016/j.aquatox.2013.12.028

20. Cristale, J., García Vázquez, A., Barata, C., Lacorte, S., 2013. Priority and emerging flame retardants in rivers: Occurrence in water and sediment, Daphnia magna toxicity and risk assessment. Environ. Int. 59, 232-243. https://doi.org/10.1016/j.envint.2013.06.011

21. Duong, H.T., Kadokami, K., Pan, S., Matsuura, N., Nguyen, T.Q., 2014. Screening and analysis of 940 organic micro-pollutants in river sediments in Vietnam using an automated identification and quantification database system for GC-MS. Chemosphere 107, 462-472. https://doi.org/10.1016/j.chemosphere.2014.01.064 
22. ECHA, 2019. European Chemicals Agency Information on chemicals. https:// echa.europa.eu/informationon-chemicals/cl-inventory-database. Accessed 13 June 2019

23. Feo, M.L., Ginebreda, A., Eljarrat, E., Barceló, D., 2010. Presence of pyrethroid pesticides in water and sediments of Ebro River Delta. J. Hydrol. 393, 156-162. https://doi.org/10.1016/j.jhydrol.2010.08.012

24. Gago-Ferrero, P., Díaz-Cruz, M.S., Barceló, D., 2011. Fast pressurized liquid extraction with in-cell purification and analysis by liquid chromatography tandem mass spectrometry for the determination of UV filters and their degradation products in sediments. Anal. Bioanal. Chem. 400, 2195-2204.

https://doi.org/10.1007/s00216-011-4951-1

25. García-Falcón, M.S., Soto-González, B., Simal-Gándara, J., 2006. Evolution of the concentrations of polycyclic aromatic hydrocarbons in burnt woodland soils. Environ. Sci. Technol. 40, 759-763. https://doi.org/10.1021/es051803v

26. García-Jares, C., Llompart, M., Polo, M., Salgado, C., Macías, S., Cela, R., 2002. Optimisation of a solid-phase microextraction method for synthetic musk compounds in water. J. Chromatogr. A 963, 277-285. https://doi.org/10.1016/S0021-9673(02)00649-0

27. Giger, W., Brunner, P., Schaffner, C., 1984. 4-Nonylphenol in Sewage Sludge: Accumulation of Toxic Metabolites from Nonionic Surfactants. Sci. 225, 623-625

28. Giokas, D.L., Salvador, A., Chisvert, A., 2007. UV filters: From sunscreens to human body and the environment. TrAC - Trends Anal. Chem. 26, 360-374. https://doi.org/10.1016/j.trac.2007.02.012

29. Goswami, P., Ohura, T., Guruge, K.S., Yoshioka, M., Yamanaka, N., Akiba, M., Munuswamy, N., 2016. Spatiotemporal distribution, source, and genotoxic potential of polycyclic aromatic hydrocarbons in estuarine and riverine sediments from southern India. Ecotoxicol. Environ. Saf. 130, 113-123.

https://doi.org/10.1016/j.ecoenv.2016.04.016

30. Ho, K.T., Mckinney, R.A., Kuhn, A., Pelletier, M.C., Burgess, R.M., 1997. Identification of acute toxicants in new bedford harbor sediments. Environ. Toxicol. Chem. 16, 551-558.

31. Huang, Y., Liu, M., Wang, R., Khan, S.K., Gao, D., Zhang, Y., 2017. Characterization and source apportionment of PAHs from a highly urbanized river sediments based on land use analysis. Chemosphere 184, 13341345. https://doi.org/10.1016/j.chemosphere.2017.06.117

32. Jones, K.C., De Voogt, P., 1999. Persistent organic pollutants (POPs): state of the science. Environ. Pollut. 100, 209-221.

33. Kaiser, D., Sieratowicz, A., Zielke, H., Oetken, M., Hollert, H., Oehlmann, J., 2012. Ecotoxicological effect characterisation of widely used organic UV filters. Environ. Pollut. 163, 84-90. https://doi.org/10.1016/j.envpol.2011.12.014

34. Kanzari, F., Syakti, A.D., Asia, L., Malleret, L., Piram, A., Mille, G., Doumenq, P., 2014. Distributions and sources of persistent organic pollutants (aliphatic hydrocarbons, PAHs, PCBs and pesticides) in surface sediments of an industrialized urban river (Huveaune), France. Sci. Total Environ. 478, 141-151. https://doi.org/10.1016/j.scitotenv.2014.01.065

35. Keshavarzifard, M., Zakaria, M.P., Shau Hwai, T., Mohamat Yusuff, F.F., Mustafa, S., Vaezzadeh, V., Magam, S.M., Masood, N., Alkhadher, S.A.A., Abootalebi-Jahromi, F., 2014. Baseline distributions and sources of Polycyclic Aromatic Hydrocarbons (PAHs) in the surface sediments from the Prai and Malacca Rivers, Peninsular Malaysia. Mar. Pollut. Bull. 88, 366-372. https://doi.org/10.1016/j.marpolbul.2014.08.014 
36. Kevin V.Thomas, Mathew McHugh, Mike Waldock, 2002. Antifouling paint booster biocides in UK coastal waters: inputs, occurrence and environmental fate. Sci. Total environement 293, 117-127. https://doi.org/10.1016/S0048-9697(01)01153-6

37. Köck-Schulmeyer, M., Ginebreda, A., Petrovic, M., Giulivo, M., Aznar-Alemany, Ò., Eljarrat, E., Valle-Sistac, J., Molins-Delgado, D., Diaz-Cruz, M.S., Monllor-Alcaraz, L.S., Guillem-Argiles, N., Martínez, E., Miren, L. de A., Llorca, M., Farré, M., Peña, J.M., Mandaric, L., Pérez, S., Majone, B., Bellin, A., Kalogianni, E., Skoulikidis, N.T., Milačič, R., Barceló, D., 2021. Priority and emerging organic microcontaminants in three Mediterranean river basins: Occurrence, spatial distribution, and identification of river basin specific pollutants. Sci. Total Environ. 754, 1-15. https://doi.org/10.1016/j.scitotenv.2020.142344

38. Kolpin, D.W., Skopec, M., Meyer, M.T., Furlong, E.T., Zaugg, S.D., 2004. Urban contribution of pharmaceuticals and other organic wastewater contaminants to streams during differing flow conditions. Sci. Total Environ. 328, 119-130. https://doi.org/10.1016/j.scitotenv.2004.01.015

39. Kouzayha, A., Al Ashi, A., Al Akoum, R., Al Iskandarani, M., Budzinski, H., Jaber, F., 2013. Occurrence of pesticide residues in lebanon's water resources. Bull. Environ. Contam. Toxicol. 91, 503-509. https://doi.org/10.1007/s00128-013-1071-y

40. Kunz, P.Y., Fent, K., 2006. Multiple hormonal activities of UV filters and comparison of in vivo and in vitro estrogenic activity of ethyl-4-aminobenzoate in fish. Aquat. Toxicol. 79, 305-324. https://doi.org/10.1016/j.aquatox.2006.06.016

41. Kunz, P.Y., Gries, T., Fent, K., 2006. The ultraviolet filter 3-benzylidene camphor adversely affects reproduction in fathead minnow (pimephales promelas). Toxicol. Sci. 93, 311-321. https://doi.org/10.1093/toxsci/kfl070

42. Landrum, P.F., Faust, W.R., 1991. Effect of variation in sediment composition on the uptake rate coefficient for selected PCB and PAH congeners by the amphipod, Diporeia sp. In: Aquatic Toxicology and Risk Assessment: Fourteenth Volume. ed. M. Mayes and M. Barron (West Conshohocken, PA: ASTM International, 1991), pp 263-279

43. Li, H., Tyler Mehler, W., Lydy, M.J., You, J., 2011. Occurrence and distribution of sediment-associated insecticides in urban waterways in the Pearl River Delta, China. Chemosphere 82, 1373-1379. https://doi.org/10.1016/j.chemosphere.2010.11.074

44. Li, H., Wei, Y., Lydy, M.J., You, J., 2014. Inter-compartmental transport of organophosphate and pyrethroid pesticides in South China: Implications for a regional risk assessment. Environ. Pollut. 190, 19-26. https://doi.org/10.1016/j.envpol.2014.03.013

45. Liu, H., Zhang, Q., Wang, Y., Cai, Z., Jiang, G., 2007. Occurrence of polychlorinated dibenzo-p-dioxins, dibenzofurans and biphenyls pollution in sediments from the Haihe River and Dagu Drainage River in Tianjin City, China. Chemosphere 68, 1772-1778. https://doi.org/10.1016/j.chemosphere.2007.03.061

46. Liu, R., Tan, R., Li, B., Song, Y., Zeng, P., Li, Z., 2015. Overview of POPs and heavy metals in Liao River Basin. Environ. Earth Sci. 73, 5007-5017. https://doi.org/10.1007/s12665-015-4317-7

47. Liu, Y., Beckingham, B., Ruegner, H., Li, Z., Ma, L., Schwientek, M., Xie, H., Zhao, J., Grathwohl, P., 2013. Comparison of sedimentary PAHs in the rivers of ammer (Germany) and liangtan (China): Differences between early-and newly-industrialized countries. Environ. Sci. Technol. 47, 701-709.

https://doi.org/10.1021/es3031566

Page 26/35 
48. Logan, D.T., 2007. Perspective on ecotoxicology of PAHs to fish. Hum. Ecol. Risk Assess. 13, 302-316. https://doi.org/10.1080/10807030701226749

49. Lohmann, R., Breivik, K., Dachs, J., Muir, D., 2007. Global fate of POPs: Current and future research directions. Environ. Pollut. 150, 150-165. https://doi.org/10.1016/j.envpol.2007.06.051

50. Ludwig, W., Probst, J.., 1998. River sediment discharge to the oceans: Present-day controls and global budgets. Am. J. Sci. 298, 265-295.

51. Magar, V.S., Brenner, R.C., Johnson, G.W., Quensen, J.F., 2005. Long-term recovery of PCB-contaminated sediments at the Lake Hartwell superfund site: PCB dechlorination. 2. Rates and extend. Environ. Sci. Technol. 39, 3548-3554. https://doi.org/10.1021/es0486216

52. Maher, W.A., Aislabie, J., 1992. Polycyclic aromatic hydrocarbons in nearshore marine sediments of Australia. Sci. Total Environ. 112, 143-164. https://doi.org/10.1016/0048-9697(92)90184-T

53. Majewski, M.S., Foreman, W.T., Goolsbys, D.A., Nakagaki, N., 1998. Airborne pesticide residues along the Mississippi River. Environ. Sci. Technol. 32, 3689-3698. https://doi.org/10.1021/es9802403

54. Maletić, S.P., Beljin, J.M., Rončević, S.D., Grgić, M.G., Dalmacija, B.D., 2019. State of the art and future challenges for polycyclic aromatic hydrocarbons is sediments: sources, fate, bioavailability and remediation techniques. J. Hazard. Mater. 365, 467-482. https://doi.org/10.1016/j.jhazmat.2018.11.020

55. Manneh, R., Abi Ghanem, C., Khalaf, G., Najjar, E., El Khoury, B., laaly, A., El Zakhem, H., 2016. Analysis of polycyclic aromatic hydrocarbons (PAHs) in Lebanese surficial sediments: A focus on the regions of Tripoli, Jounieh, Dora, and Tyre. Mar. Pollut. Bull. 110, 578-583.

56. Massoud, M.A., El-Fadel, M., Scrimshaw, M.D., Lester, J.N., 2006. Factors influencing development of management strategies for the Abou Ali River in Lebanon. I: Spatial variation and land use. Sci. Total Environ. 362, 15-30. https://doi.org/10.1016/j.scitotenv.2005.09.079

57. Merhaby, D., Net, S., Halwani, J., Ouddane, B., 2015. Organic pollution in surficial sediments of Tripoli harbour, Lebanon. Mar. Pollut. Bull. 93, 284-293. https://doi.org/10.1016/j.marpolbul.2015.01.004

58. Naja, G.M., Volesky, B., 2013. Sewage of Tripoli: a review of the current situation and of the future planning. Int. J. Environ. Technol. Manag. 16, 312-325. https://doi.org/10.1504/ijetm.2013.054879

59. Navarro, A., Tauler, R., Lacorte, S., Barceló, D., 2010. Occurrence and transport of pesticides and alkylphenols in water samples along the Ebro River Basin. J. Hydrol. 383, 18-29.

https://doi.org/10.1016/j.jhydrol.2009.06.039

60. Nemr, A. El, Said, T.O., Khaled, A., El-Sikaily, A., Abd-Allah, A.M.A., 2007. The distribution and sources of polycyclic aromatic hydrocarbons in surface sediments along the Egyptian Mediterranean coast. Environ. Monit. Assess. 124, 343-359. https://doi.org/10.1007/s10661-006-9231-8

61. Net, S., El-Osmani, R., Prygiel, E., Rabodonirina, S., Dumoulin, D., Ouddane, B., 2015. Overview of persistent organic pollution (PAHs, Me-PAHs and PCBs) in freshwater sediments from Northern France. J. Geochemical Explor. 148, 181-188. https://doi.org/10.1016/j.gexplo.2014.09.008

62. Nguyen, T.C., Loganathan, P., Nguyen, T.V., Vigneswaran, S., Kandasamy, J., Slee, D., Stevenson, G., Naidu, R., 2014. Polycyclic aromatic hydrocarbons in road-deposited sediments, water sediments, and soils in Sydney, Australia: Comparisons of concentration distribution, sources and potential toxicity. Ecotoxicol. Environ. Saf. 104, 339-348. https://doi.org/10.1016/j.ecoenv.2014.03.010 
63. Nicolau, R., Lucas, Y., Merdy, P., Raynaud, M., 2012. Base flow and stormwater net fluxes of carbon and trace metals to the Mediterranean sea by an urbanized small river. Water Res. 46, 6625-6637.

https://doi.org/10.1016/j.watres.2012.01.031

64. OSPAR Commission, 2004. OSPAR background document on musk xylene and other musks. http://www.ospar.org/documents?v=6978. Accessed 26 April 2019

65. Peck, A.M., Hornbuckle, K.C., 2004. Synthetic Musk Fragrances in Lake Michigan. Environ. Sci. Technol. 38, 367-372. https://doi.org/10.1021/es034769y

66. Peck, A.M., Linebaugh, E.K., Hornbuckle, K.C., 2006. Synthetic musk fragrances in Lake Erie and Lake Ontario sediment cores. Environ. Sci. Technol. 40, 5629-5635. https://doi.org/10.1021/es060134y

67. Peng, X., Xiong, S., Ou, W., Wang, Z., Tan, J., Jin, J., Tang, C., Liu, J., Fan, Y., 2017. Persistence, temporal and spatial profiles of ultraviolet absorbents and phenolic personal care products in riverine and estuarine sediment of the Pearl River catchment, China. J. Hazard. Mater. 323, 139-146.

https://doi.org/10.1016/j.jhazmat.2016.05.020

68. Phillips, B.M., Anderson, B.S., Hunt, J.W., Siegler, K., Voorhees, J.P., Tjeerdema, R.S., Mcneill, K., 2012. Pyrethroid and organophosphate pesticide-associated toxicity in two coastal watersheds (California, USA). Environ. Toxicol. Chem. 31, 1595-1603. https://doi.org/10.1002/etc.1860

69. Pintado-Herrera, M.G., Combi, T., Corada-Fernández, C., González-Mazo, E., Lara-Martín, P.A., $2017 a$. Occurrence and spatial distribution of legacy and emerging organic pollutants in marine sediments from the Atlantic coast (Andalusia, SW Spain). Sci. Total Environ. 605-606, 980-994.

https://doi.org/10.1016/j.scitotenv.2017.06.055

70. Pintado-Herrera, M.G., González-Mazo, E., Lara-Martín, P.A., 2016. In-cell clean-up pressurized liquid extraction and gas chromatography-tandem mass spectrometry determination of hydrophobic persistent and emerging organic pollutants in coastal sediments. J. Chromatogr. A 1429, 107-118.

https://doi.org/10.1016/j.chroma.2015.12.040

71. Pintado-Herrera, M.G., Wang, C., Lu, J., Chang, Y.P., Chen, W., Li, X., Lara-Martín, P.A., 2017b. Distribution, mass inventories, and ecological risk assessment of legacy and emerging contaminants in sediments from the Pearl River Estuary in China. J. Hazard. Mater. 323, 128-138.

https://doi.org/10.1016/j.jhazmat.2016.02.046

72. Quantin, C., Joner, E.J., Portal, J.M., Berthelin, J., 2005. PAH dissipation in a contaminated river sediment under oxic and anoxic conditions. Environ. Pollut. 134, 315-322.

https://doi.org/10.1016/j.envpol.2004.07.022

73. Rodil, R., Moeder, M., 2008. Development of a simultaneous pressurised-liquid extraction and clean-up procedure for the determination of UV filters in sediments. Anal. Chim. Acta 612, 152-159. https://doi.org/10.1016/j.aca.2008.02.030

74. Roy, S., Gaillardet, J., Allègre, C.J., 1999. Geochemistry of dissolved and suspended loads of the Seine river, France: Anthropogenic impact, carbonate and silicate weathering. Geochim. Cosmochim. Acta 63, 12771292.

75. Sieratowicz, A., Kaiser, D., Behr, M., Oetken, M., Oehlmann, J., 2011. Acute and chronic toxicity of four frequently used UV filter substances for Desmodesmus subspicatus and Daphnia magna. J. Environ. Sci. Heal. - Part A Toxic/Hazardous Subst. Environ. Eng. 46, 1311-1319.

https://doi.org/10.1080/10934529.2011.602936

Page 28/35 
76. Sindermann, C., 2005. Coastal Pollution Effects on Living Resources and Humans. Boca Raton, USA. https://doi.org/https://doi.org/10.1201/9781420036411

77. Sinkkonen, S., Paasivirta, J., 2000. Degradation half-life times of PCDDs, PCDFs and PCBs for environmental fate modeling. Chemosphere 40, 943-949. https://doi.org/10.1016/S0045-6535(99)00337-9

78. SOER (State of the Environment Report), 2001. Ministry of environment and the Lebanese environment and development observatory. ECODIT, 240 pp. http://www.moe.gov.lb/ledo/soer2001pdf/chpt12_ins.pdf. Accessed 09 July 2019

79. Soukarieh, B., El Hawari, K., El Husseini, M., Budzinski, H., Jaber, F., 2018. Impact of Lebanese practices in industry, agriculture and urbanization on soil toxicity. Evaluation of the Polycyclic Aromatic Hydrocarbons (PAHs) levels in soil. Chemosphere 210, 85-92.

https://doi.org/https://doi.org/10.1016/j.chemosphere.2018.06.178

80. Souza, M.R.R., Santos, E., Suzarte, J.S., Carmo, L.O., Frena, M., Damasceno, F.C., Alexandre, M.R., 2018. Concentration, distribution and source apportionment of polycyclic aromatic hydrocarbons (PAH) in Poxim River sediments, Brazil. Mar. Pollut. Bull. 127, 478-483. https://doi.org/10.1016/j.marpolbul.2017.12.045

81. Sun, L., Zuo, Z., Chen, M., Chen, Y., Wang, C., 2015. Reproductive and transgenerational toxicities of phenanthrene on female marine medaka (Oryzias melastigma). Aquat. Toxicol. 162, 109-116. https://doi.org/10.1016/j.aquatox.2015.03.013

82. Tang, Z., Han, X., Li, G., Tian, S., Yang, Y., Zhong, F., Han, Y., Yang, J., 2018. Occurrence, distribution and ecological risk of ultraviolet absorbents in water and sediment from Lake Chaohu and its inflowing rivers, China. Ecotoxicol. Environ. Saf. 164, 540-547. https://doi.org/10.1016/j.ecoenv.2018.08.045

83. Thomas, R.L., Shaban, A., Khawlie, M., Kawass, I., Nsouli, B., 2005. Geochemistry of the sediments of the ElKabir River and Akkar watershed in Syria and Lebanon. Lakes Reserv. Res. Manag. 10, 127-134. https://doi.org/10.1111/j.1440-1770.2005.00267.x

84. Torres, T., 2013. Contribution to the toxicological risk assessment of Simvastatin, Sertraline, 4-MBC, Propylparaben and Triclocarban, under single and combined exposure, using zebrafish and sea urchin embryo bioassays.

85. Totten, L.A., Panangadan, M., Eisenreich, S.J., Cavallo, G.J., Fikslin, T.J., 2006. Direct and indirect atmospheric deposition of PCBs to the Delaware River watershed. Environ. Sci. Technol. 40, 2171-2176. https://doi.org/10.1021/es052149m

86. Tsui, M.M.P., Leung, H.W., Wai, T.C., Yamashita, N., Taniyasu, S., Liu, W., Lam, P.K.S., Murphy, M.B., 2014. Occurrence, distribution and ecological risk assessment of multiple classes of UV filters in surface waters from different countries. Water Res. 67, 55-65. https://doi.org/10.1016/j.watres.2014.09.013

87. Tu, Y.T., Ou, J.H., Tsang, D.C.W., Dong, C.D., Chen, C.W., Kao, C.M., 2018. Source identification and ecological impact evaluation of PAHs in urban river sediments: A case study in Taiwan. Chemosphere 194, 666-674. https://doi.org/10.1016/j.chemosphere.2017.12.008

88. UNEP, 2009. Rapid Environmental Assessment of The Urban Community of Al-Fayha', Lebanon. https://wedocs.unep.org/bitstream/handle/20.500.11822/20837/REA_AlFayhaaUrbanCommunityfinal.pdf? sequence=1\&isAllowed=y. Accessed 15 April 2019

89. United States Environmental Protection Agency (EPA), 2001. EMERGENCY PLANNING AND COMMUNITY RIGHT-TO-KNOW ACT - SECTION 313: Guidance for Reporting Toxic Chemicals: Polycyclic Aromatic 
Compounds Category. Office of Environmental Information Washington, DC 20460.

https://www.epa.gov/sites/production/files/documents/2001 pacs.pdf. Accessed 12 April 2019

90. US EPA, 2007. Method 3545A Pressurized fluid extraction.

https://www.epa.gov/sites/production/files/2015-12/documents/3545a.pdf. Accessed 16 June 2019

91. Vane, C.H., Harrison, I., Kim, A.W., 2007. Polycyclic aromatic hydrocarbons (PAHs) and polychlorinated biphenyls (PCBs) in sediments from the Mersey Estuary, U.K. Sci. Total Environ. 374, 112-126.

https://doi.org/10.1016/j.scitotenv.2006.12.036

92. Vignet, C., Devier, M.H., Le Menach, K., Lyphout, L., Potier, J., Cachot, J., Budzinski, H., Bégout, M.L., Cousin, X., 2014. Long-term disruption of growth, reproduction, and behavior after embryonic exposure of zebrafish to PAH-spiked sediment. Environ. Sci. Pollut. Res. 21, 13877-13887. https://doi.org/10.1007/s11356-0142585-5

93. Villa, S., Assi, L., Ippolito, A., Bonfanti, P., Finizio, A., 2012. First evidences of the occurrence of polycyclic synthetic musk fragrances in surface water systems in Italy: Spatial and temporal trends in the Molgora River (Lombardia Region, Northern Italy). Sci. Total Environ. 416, 137-141.

https://doi.org/10.1016/j.scitotenv.2011.11.027

94. Vimalkumar, K., Arun, E., Krishna-Kumar, S., Poopal, R.K., Nikhil, N.P., Subramanian, A., Babu-Rajendran, R., 2018. Occurrence of triclocarban and benzotriazole ultraviolet stabilizers in water, sediment, and fish from Indian rivers. Sci. Total Environ. 625, 1351-1360. https://doi.org/10.1016/j.scitotenv.2018.01.042

95. Wang, J., Pan, L., Wu, S., Lu, L., Xu, Y., Zhu, Y., Guo, M., Zhuang, S., 2016. Recent advances on endocrine disrupting effects of UV filters. Int. J. Environ. Res. Public Health 782, 2-11. https://doi.org/10.3390/ijerph13080782

96. Wang, Q., Kelly, B.C., 2017. Occurrence and distribution of synthetic musks, triclosan and methyl triclosan in a tropical urban catchment: Influence of land-use proximity, rainfall and physicochemical properties. Sci. Total Environ. 574, 1439-1447. https://doi.org/10.1016/j.scitotenv.2016.08.091

97. Wentsel, R.S., Lapoint, T.W., Simini, M., Checkai, R.T., Ludwig, D., 1996. Tri service procedural guidelines for ecologicl risk assessment. Aberdeen Proving Ground, MDUS Army Edgewood Res. Dev. Engeneering Cent.

98. Weston, D.P., Holmes, R.W., Lydy, M.J., 2009. Residential runoff as a source of pyrethroid pesticides to urban creeks. Environ. Pollut. 157, 287-294. https://doi.org/10.1016/j.envpol.2008.06.037

99. Witt, G., 1995. Polycyclic Aromatic Hydrocarbons in Water and Sediment of the Baltic Sea. Mar. Pollut. Bull. 31, 237-248.

100. Xu, P., Tao, B., Ye, Z., Zhao, H., Ren, Y., Zhang, T., Huang, Y., Chen, J., 2016. Polycyclic aromatic hydrocarbon concentrations, compositions, sources, and associated carcinogenic risks to humans in farmland soils and riverine sediments from Guiyu, China. J. Environ. Sci. (China) 48, 102-111.

https://doi.org/10.1016/j.jes.2015.11.035

101. Ying, G.G., Williams, B., Kookana, R., 2002. Environmental fate of alkylphenols and alkylphenol ethoxylates A review. Environ. Int. 28, 215-226. https://doi.org/10.1016/S0160-4120(02)00017-X

102. Youssef, L., Younes, G., Kouzayha, A., Jaber, F., 2015. Occurrence and levels of pesticides in South Lebanon water. Chem. Speciat. Bioavailab. 27, 62-70. https://doi.org/10.1080/09542299.2015.1023092

103. Yunker, M.B., Macdonald, R.W., Vingarzan, R., Mitchell, R.H., Goyette, D., Sylvestre, S., 2002. PAHs in the Fraser River basin: a critical appraisal of PAH ratios as indicators of PAH source and composition. Org. 
Geochemistry 33, 489-515.

104. Zeng, E.Y., Bay, S.M., Greenstein, D., Vista, C., Yu, C., Ritter, K., 2003. Toxic effects of polychlorinate biphenyl bioaccumulation in sea urchins exposed to contaminated sediments. Environ. Toxicol. Chem. 22, 10651074.

105. Zeng, Q., Jeppesen, E., Gu, X., Mao, Z., Chen, H., 2018. Distribution, fate and risk assessment of PAHs in water and sediments from an aquaculture- and shipping-impacted subtropical lake, China. Chemosphere 201, 612-620. https://doi.org/10.1016/j.chemosphere.2018.03.031

106. Zeng, X., Mai, B., Sheng, G., Lou, X., Shao, W., An, T., Fu, J., 2008. Distribution of polycyclic musks in surface sediments from the Pearl River Delta and Macao coastal region, South China. Environ. Toxicol. Chem. 27, 18-23. https://doi.org/10.1897/07-106.1

107. Zeng, X., Xu, L., Liu, J., Wu, Y., Yu, Z., 2018. Occurrence and distribution of organophosphorus flame retardants/plasticizers and synthetic musks in sediments from source water in the Pearl River Delta, China. Environ. Toxicol. Chem. 37, 975-982. https://doi.org/10.1002/etc.4040

108. Zhang, A., Zhao, S., Wang, L., Yang, X., Zhao, Q., Fan, J., Yuan, X., 2016. Polycyclic aromatic hydrocarbons (PAHs) in seawater and sediments from the northern Liaodong Bay, China. Mar. Pollut. Bull. 113, 592-599. https://doi.org/10.1016/j.marpolbul.2016.09.005

109. Zhao, L., Hou, H., Zhou, Y.Y., Xue, N.D., Li, H.Y., Li, F.S., (2010). Distribution and ecological risk of polychlorinated biphenyls and organochlorine pesticides in surficial sediments from Haihe River and Haihe Estuary Area, China. Chemosphere 78, 1285-1293. https://doi.org/10.1016/j.chemosphere.2009.12.007

\section{Figures}

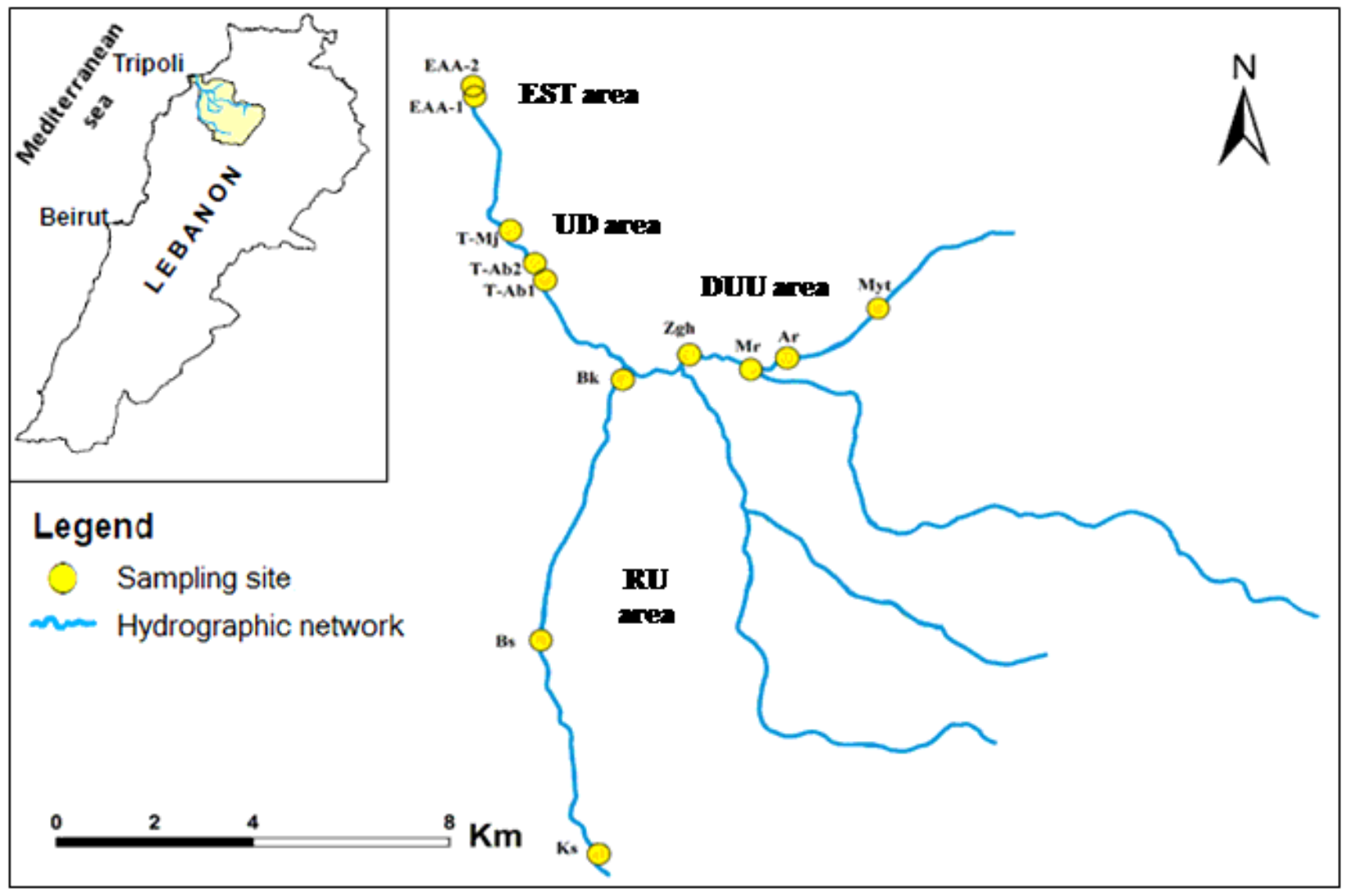


Figure 1

Location of the sampling sites in Kadicha river basin. The sites are presented by their code: Ks for Koussba, Bs for Bshennine and Bk for Bkeftine in the rural upstream area (RU), Myt for Meryata, Ar for Ardeh, Mr for Al Merdechyeh and Zgh for Zgharta in the discontinuous urbanized upstream area (DUU), T-Ab 1 and 2 for Abou Samra and T-Mj for Al Marjeh in the urbanized downstream area (UD), EAA-1 and 2 for the estuary in the estuary area (EST). Note: The designations employed and the presentation of the material on this map do not imply the expression of any opinion whatsoever on the part of Research Square concerning the legal status of any country, territory, city or area or of its authorities, or concerning the delimitation of its frontiers or boundaries. This map has been provided by the authors.

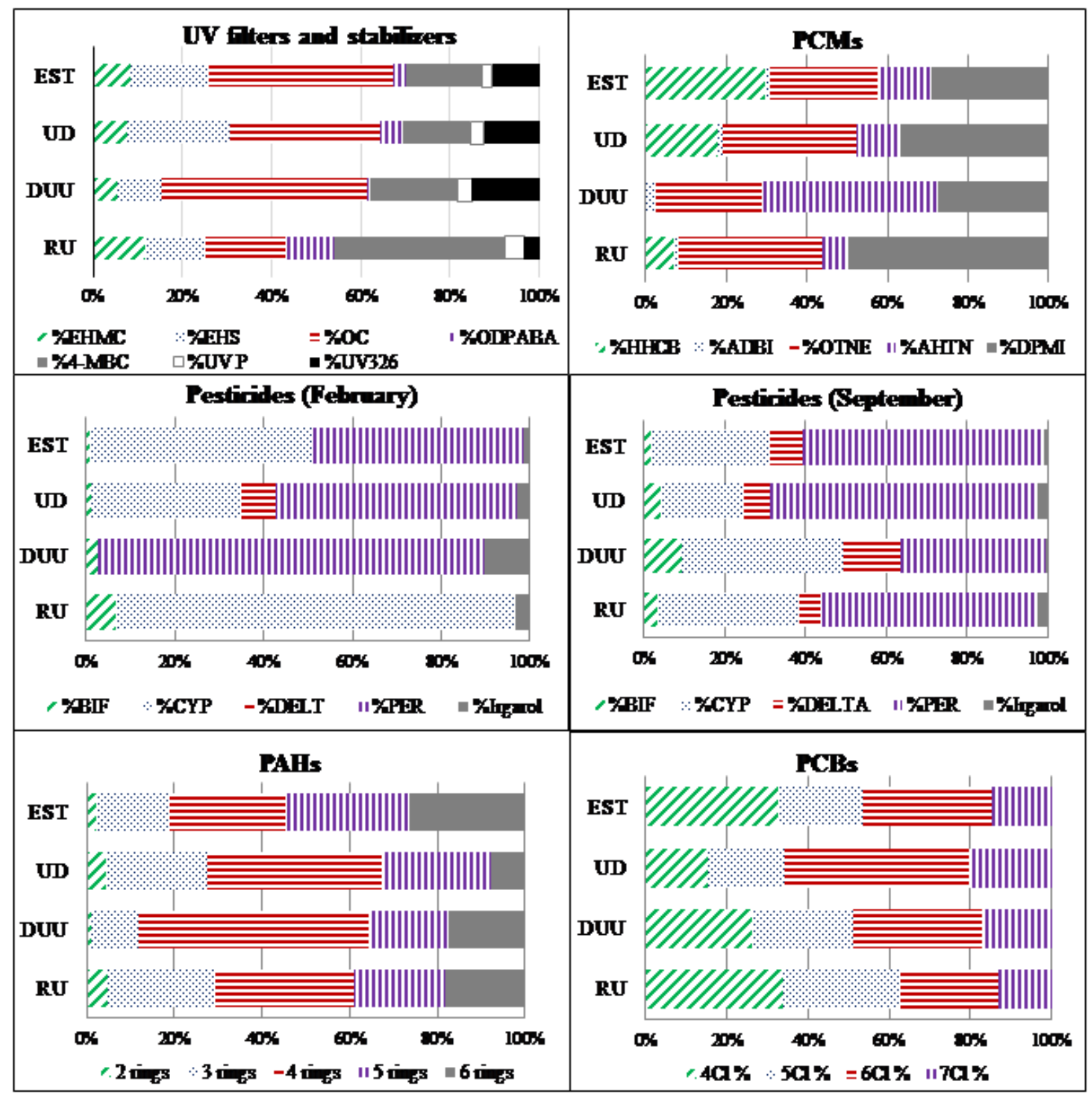

Figure 2 
Distribution patterns of contaminants shown in mass percentage for each class within the 4 studied areas: rural upstream (RU), discontinuous urbanized upstream (DUU), urbanized downstream (UD), and estuary (EST). The pesticides show a seasonal variation between the 2 surveys.

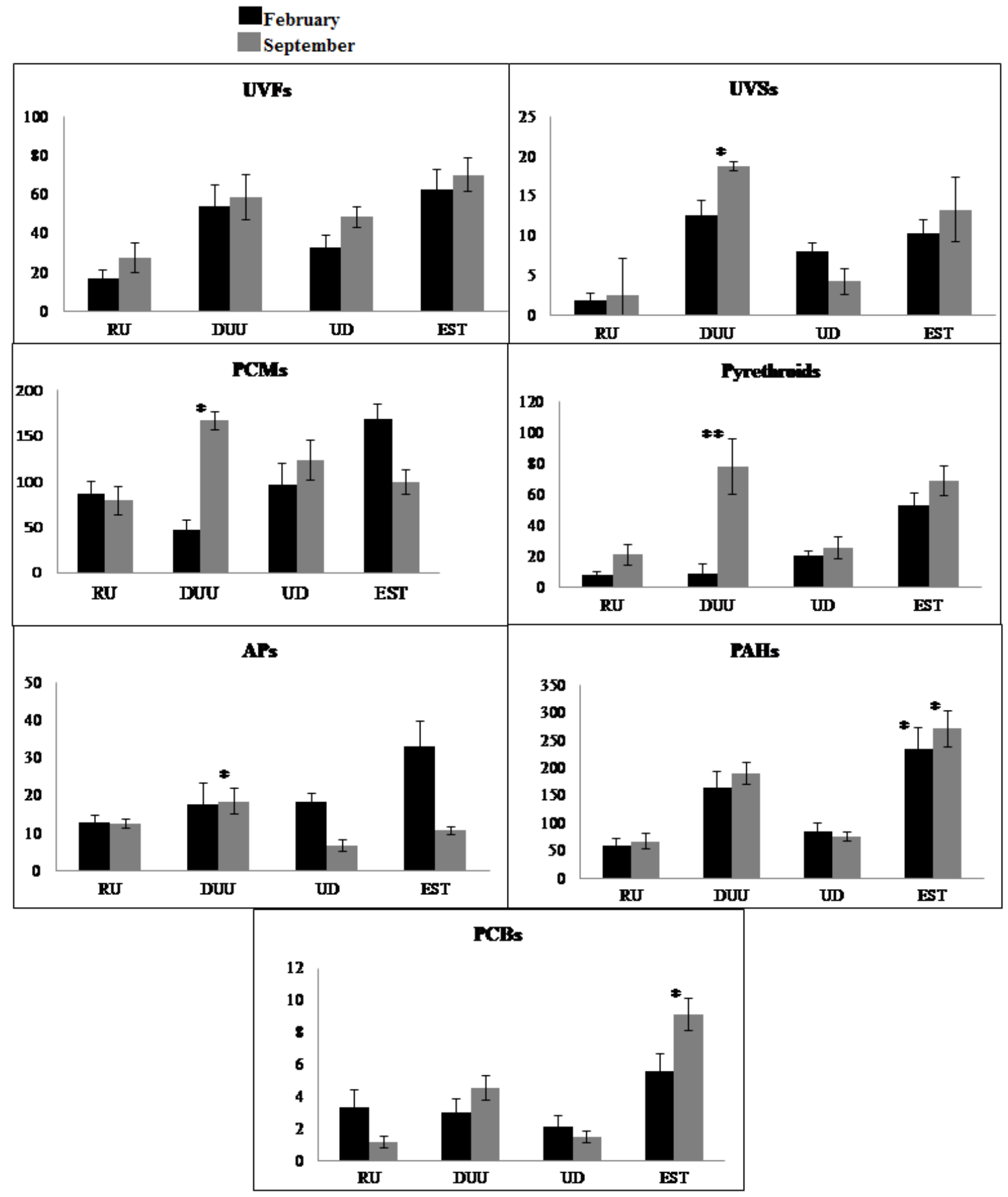

Figure 3

Total concentrations of contaminants for each class within the four studied areas: rural upstream (RU), discontinuous urbanized upstream (DUU), urbanized downstream (UD), and estuary (EST). Concentrations are in $\mathrm{ng} / \mathrm{g}$ d.w. The $\mathrm{p}$-values indicate significant difference (Post Hoc test - Fisher LSD) between mean values of the 
studied variable from one sampling area to the three other areas at the $95 \%$ confidence level $\left(p-v a l u e<0.05^{\star}, p-\right.$ value $\left.<0.01^{\star \star}\right)$.

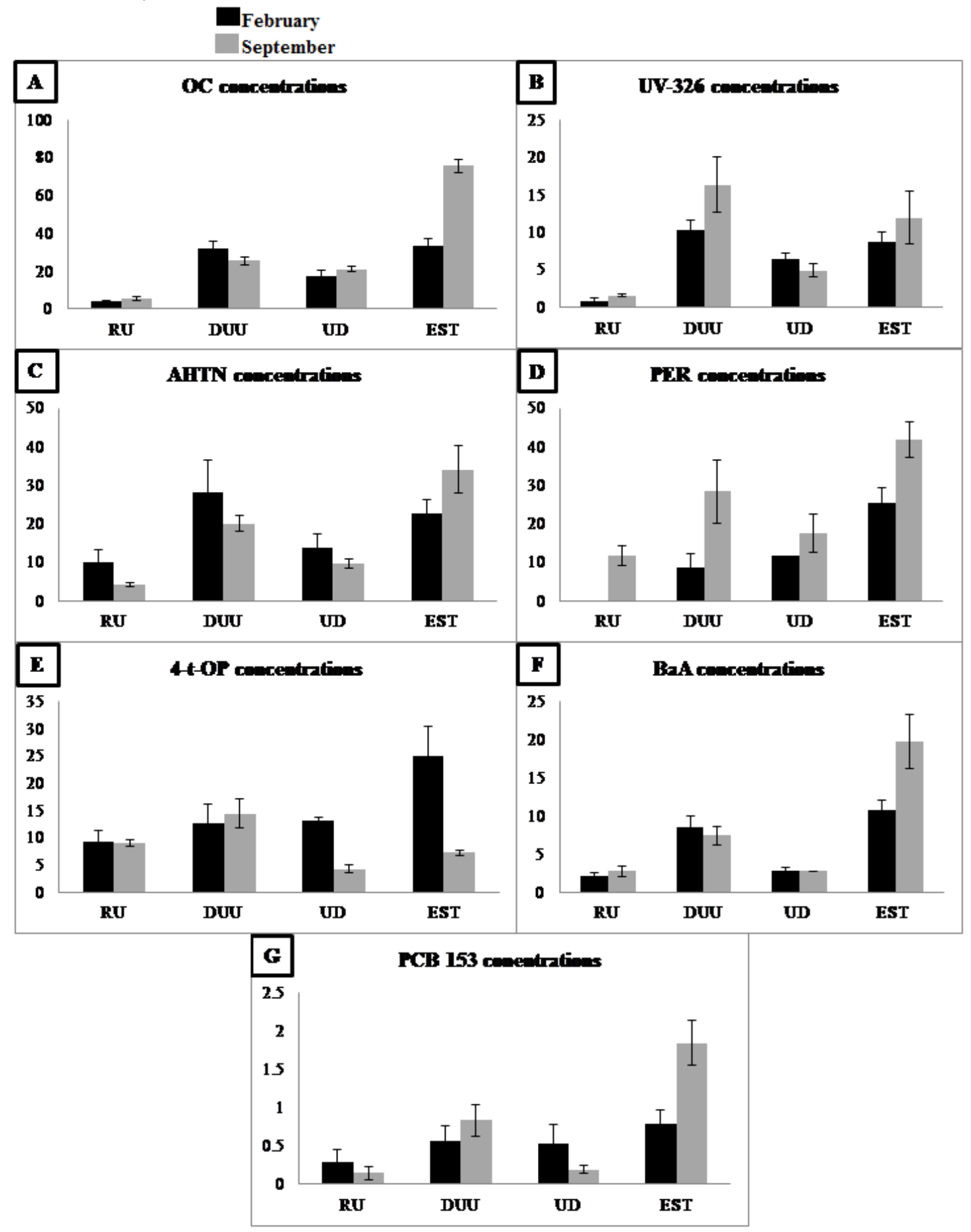

Figure 4

Concentrations of contaminants among each class for the two months surveys (February and September) within the four studied areas: rural upstream (RU), discontinuous urbanized upstream (DUU), urbanized downstream (UD), and estuary (EST). A: concentrations of OC; B: concentrations of UV-326; C: Concentrations of tonalide (AHTN); D: concentrations of PER (permethrin); E: concentrations of 4-t-OP; F: concentrations of BaA (benzo[a]anthracene); G: concentrations of PCB 153. Concentrations are in ng/g d.w. 


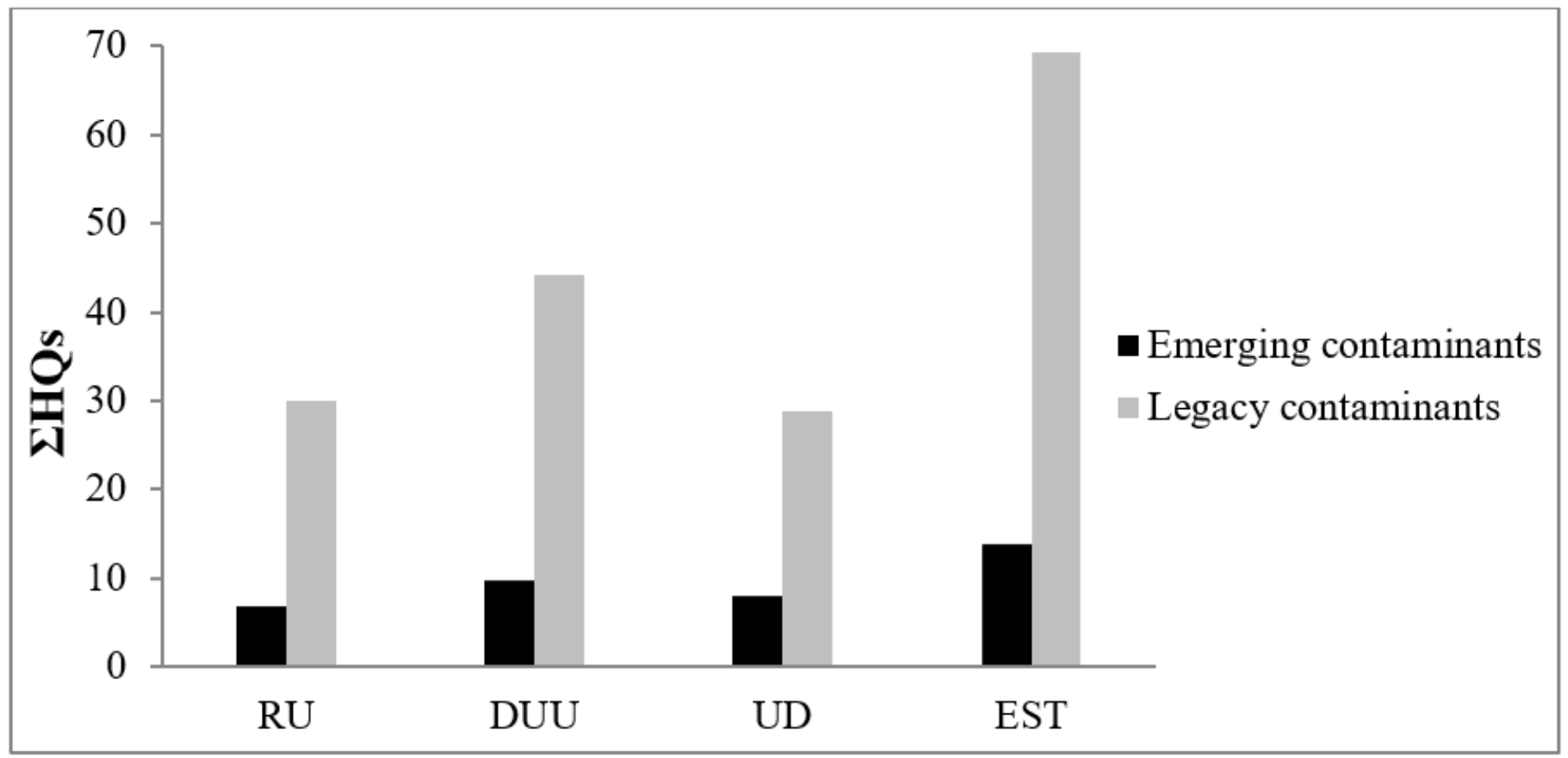

Figure 5

Spatial distribution of $\mathrm{HQQ}_{\mathrm{s}}$ for emerging and legacy compounds within the four studied areas: rural upstream $(R U)$, discontinuous urbanized upstream (DUU), urbanized downstream (UD), and estuary (EST).

\section{Supplementary Files}

This is a list of supplementary files associated with this preprint. Click to download.

- ESM1.docx 